\title{
Medievalista
}

Online

22 | 2017

Número 22

\section{O couro lavrado de estética mudéjar na Casa-Museu e Fundação Guerra Junqueiro - memórias do al- Andalus em terras portuguesas}

Leather carvings of mudéjar aesthetics at the Guerra Junqueiro House-Museum and Foundation - memories of al-Andalus in Portuguese lands

\section{Franklin Pereira}

\section{OpenEdition}

Journals

\section{Edição electrónica}

URL: http://journals.openedition.org/medievalista/1344

DOI: $10.4000 /$ medievalista.1344

ISSN: $1646-740 X$

\section{Editora}

Instituto de Estudos Medievais - FCSH-UNL

\section{Refêrencia eletrónica}

Franklin Pereira, "O couro lavrado de estética mudéjar na Casa-Museu e Fundação Guerra Junqueiro

- memórias do al-Andalus em terras portuguesas », Medievalista [Online], 22 | 2017, posto online no dia 01 dezembro 2017, consultado o 10 dezembro 2020. URL : http://journals.openedition.org/ medievalista/1344; DOI : https://doi.org/10.4000/medievalista.1344 
Título / Title: O couro lavrado de estética mudéjar na Casa-Museu e Fundação Guerra Junqueiro - memórias do al-Andalus em terras portuguesas / Leather carvings of mudéjar aesthetics at the Guerra Junqueiro House-Museum and Foundation - memories of alAndalus in Portuguese lands

Autor(es) / Author(s): Franklin Pereira

Universidade / University: Universidade de Lisboa

Faculdade e Departamento / Unidade de Investigação - Faculty and Department / Research Center: Faculdade de Letras, Artis - Instituto de História da Arte da

Código Postal / Postcode: 1600-190

Cidade / City: Lisboa

País / Country: Portugal

Email Institucional / Institutional email: frankleather@yahoo.com

Fonte: Medievalista [Em linha]. Direc. Bernardo Vasconcelos e Sousa. Lisboa: IEM.

Disponível em:

http://www2.fcsh.unl.pt/iem/medievalista/MEDIEVALISTA22/pereira2205.html

ISSN: 1646-740X

Data recepção do artigo / Received for publication: 30 de Junho de 2016

Data aceitação do artigo / Accepted in revised form: 22 de Fevereiro de 2016 


\section{Resumo}

$\mathrm{O}$ autor centra-se em três cadeiras e cinco estofos soltos das colecções do poeta Guerra Junqueiro, actualmente na Casa-Museu e Fundação com o seu nome; o couro lavrado apresenta particularidades estéticas que o fazem integrar na arte mudéjar de linhagem omíada que permaneceu no ocidente peninsular depois da Reconquista. As relações que estes motivos permitem considerar salientam Portugal como depósito de continuidades e adaptações de estéticas arcaicas; ficaram na arte do couro da elite c.1500-1600, antes dos padrões renascentistas se terem tornado dominantes.

Palavras-chave: Legado islâmico; Arte mudéjar; Couro lavrado; Mobiliário português; Cadeiras.

\section{Abstract}

The author analyses three chairs and five upholstery pieces of the collection of the poet Guerra Junqueiro, nowadays at the House-Museum and Foundation bearing his name; these leather carvings show aesthetical peculiarities that turn them part of Mudejar art of Umayyad lineage that remained in the West of Iberia Peninsula after the Reconquest. The connections that such motives allow highlight Portugal as a deposit of continuities and adaptations of archaic aesthetics; they have remained in the elite's leather art c. 1500-1600 before the Renaissance motives becoming dominant.

Keywords: Islamic legacy; Mudejar art; Carved leather; Portuguese furniture; Chairs. 


\section{O couro lavrado de estética mudéjar na Casa-Museu e} Fundação Guerra Junqueiro - memórias do al-Andalus em terras portuguesas / Leather carvings of mudéjar aesthetics at the Guerra Junqueiro House-Museum and Foundation - memories of al-Andalus in Portuguese

\section{lands}

\section{Franklin Pereira}

Inicio este texto com uma citação de R. W. Hamilton: "The causal links between such simple motives in their manifold variants, distributed in widely separated regions between many crafts, present the kind of problems apt to generate profitless speculation which the available materials can never resolve"1. Não subscrevo esta opinião, pelo prazer das viagens que encerra, da descoberta, pela importância em descodificar estéticas e de as fazer ingressar na História de Arte; na Península Ibérica há que considerar a herança de motivos arcaicos no couro utilizado para estofos, motivos esses passados entre manufacturas e viajados entre geografias. Apoio-me, antes, numa outra visão: "Nearly all media, except for the art of the book, are represented and in many instances, as with ivories, there is a critical mass of works which should allow for reflections and conclusions on classical art historical topics such as sources, styles, subject matter, and expression" 2 .

As peças lavradas adiante apresentadas - cadeiras completas (peças $n^{\circ} \mathrm{s} 1,2,3$ ) da CasaMuseu Guerra Junqueiro (CMGJ) e estofos soltos (peças no 4 a 8) da Fundação Guerra

\footnotetext{
${ }^{1}$ HAMILTON, R. W. - Khirbat al-Mafjar: an Arabian mansion in the Jordan valley. Oxford: Claredom Press, 1959, p. 213.

${ }^{2}$ ETTINGHAUSEN, Richard - "Notes on the lusterware of Spain". Ars Orientalis I (1954), pp. 133-156, p. 100.
} 
Junqueiro (FGJ) - pertencem ao núcleo mais antigo do panorama da gravura em Portugal; são da época de transição entre as modas mudéjares e o Renascimento, com o uso mais frequente da cadeira. A descodificação das estéticas destes estofos transportanos à época medieval peninsular, com um relevo particular dado ao sul islâmico.

Saliente-se, ainda, a mente coleccionista do poeta Guerra Junqueiro; a colecção de cadeiras lavradas e guadamecis mostra a consideração que tinha pelas artes do couro, não só devido à abundância de móveis de assento, mas por recolher estofos soltos como alguns destes em estudo - que, devido à sua secura e cortes, nunca poderiam tornar-se funcionais. O mesmo digo quanto aos guadamecis, também da FGJ, todos eles da indústria repetitiva dos Países Baixos do século XVIII ${ }^{3}$ : se a cortina ainda poderia ter alguma utilidade ou servir de ornamento, os restantes fragmentos são inúteis para um restauro; mostram, tão-só, como o poeta estimava estas manifestações.

A estética islâmica foi recriada na arte mudéjar, onde as alcatifas e estrados atapetados, coxins, panejamentos em têxtil ou guadameci são os aspectos mais salientes nos interiores abastados, em usos que perduraram até inícios do século XVII. Uma outra vertente ficou reduzida às manifestações populares do sul ibérico, prolongando-se nos artefactos típicos como os safões e sacos de pastores ${ }^{4}$. Relativamente aos couros da época islâmica, pouquíssimo sobreviveu; resumem-se a duas aljavas ${ }^{5}$, com a técnica do calado - que veremos continuada na arte pastoril do sul ibérico - e duas adargas nazarís ${ }^{6}$.

\footnotetext{
${ }^{3}$ PEREIRA, Franklin - "Couros dourados" / guadamecis dos Países Baixos em Portugal (séculos XVIIXVIII)". Al-Madan, 2a série, 19/2 (Janeiro 2015), pp. 117-132, pp. 127-128.

${ }^{4}$ PEREIRA, Franklin - "A arte dos pastores do sul peninsular: arquétipos em final de estrada". in Actas das III Jornadas Internacionais de Vestígios do Passado / Almeida, 2007. Póvoa do Varzim: AGIR / Associação para o Desenvolvimento Sócio-cultural, 2007, p. 220; PEREIRA, Franklin - "A sul do rio Mondego. Arcaísmo, simbologia e transmigração de ornamentos nas artes populares do sul ibérico". A Cidade de Évora, $2^{a}$ série, 7 (2009), pp. 540-542; PEREIRA, Franklin - "Eqqus cursare - uma viagem a partir do Festival Anual do Cavalo na Golegã". Nova Augusta 22 (2010), pp. 176-177; PEREIRA, Franklin - "Estéticas em trânsito: a partilha do ornamento da cerâmica do Gharb al-Andalus com outros artefactos". Arqueologia Medieval 12 (Outubro 2012), p. 199.

${ }^{5}$ PEREIRA, Franklin - "Cueros artísticos en el Museo Arqueológico Nacional". Boletín del Museo Arqueológico Nacional 20 (2002), pp. 237-238; PEREIRA, Franklin - "A sul do rio Mondego", p. 541.

${ }^{6}$ PÉREZ HIGUERA, Teresa - Objetos y imagenes de al-Andalus. Madrid: Editorial Lundwerg, 1994, p. 124; (AL-)ANDALUS: las artes islámicas en España. Madrid: Ediciones El Viso, 1992, p. 296; PEREIRA, Franklin - "Eqqus cursare”, p. 171.
} 
De referir ainda os apetrechos do último sultão - botas, sapatos, espada e bainha bordada, adaga em bainha incisa, carteira e cinto, pequena bolsa de ombro ${ }^{7}$, , onde a decoração é sobretudo realizada pelo bordado com fio de prata; existe ainda uma cadeira dobradiça no Palácio de Alhambra $^{8}$, de couros muito secos; a sua estética, lavrada no couro bovino do encosto e assento, retoma as linhas básicas vistas noutras manifestações, como a cerâmica ou têxtil: escudo da dinastia nazarí, laçaria exterior e animais estilizados. $\mathrm{O}$ mesmo museu possui um chapim em guadameci, pintado com um animal olhando sobre o ombro, entre folhagem estilizada, e moldura de encordoado 9 .

O Museu de l'Art de la Pell (em Vic, Espanha) expõe um guadameci árabe do século $\mathrm{XIV}^{10}$ e uma sanefa na mesma técnica e datação ${ }^{11}$, sem especificar se é andalusí; integra ainda uma cortina em padrão de hexágonos alongados (século XIV) ${ }^{12}$, uma caixa octogonal, com um motivo de entrançado com ferreteado típico das encadernações, com pontos dourados, e datada do século $\mathrm{XIV}^{13}$, e uma cortina gofrada de padrão em pequenos trapézios, já do século $\mathrm{XVI}^{14}$.

Outros dados podem ser retirados de encadernações muçulmanas ${ }^{15}$ e mudéjares ${ }^{16}$, e de raros guadamecis do século $\mathrm{XVI}^{17}$, revelando permanência e partilha de estéticas:

\footnotetext{
7 (AL-)ANDALUS, pp. 288, 291, 293; PEREIRA, Franklin - "Identidade e memória nas artes do couro de linhagem ibero-muçulmana”. in Actas do I Seminário Internacional de Memória e Cultura Visual/ Póvoa do Varzim, 2007. Póvoa do Varzim: AGIR/Associação para o Desenvolvimento Sócio-cultural, 2008, p. 208.

8 PEREIRA, Franklin - As cadeiras em couro lavrado e os guadamecis do Museu de Pontevedra. Pontevedra: Museu de Pontevedra, 2000, p. 245; PEREIRA, Franklin - "Leather decoration tools of the Iberian tradition, since the 13th century". Tools and Trades 12 (2000), p. 11.

9 MATILDA ANDERSON, Ruth - "El chapin y otros zapatos de la Alhambra". Cuadernos de la Alhambra 5 (1969), pp. 17-41; PEREIRA, Franklin - "Leather decoration tools", p. 22; PEREIRA, Franklin - "Identidade e memória", p. 209.

${ }^{10}$ ART en la pell: cordovans i guadamassils de la col.lecció Colomer Munmany. Barcelona: Fundació la Caixa / Generalitat de Catalunya, 1992, p. 73, imagem 47.

${ }^{11}$ ART en la pell, p. 73, imagem 48.

${ }^{12} A R T$ en la pell, p. 72, imagem 46.

13 (EL) ARTE en la piel - Colección A. Colomer Munmany. Madrid: Fundación Central Hispano / Museu de l'Art de la Pell, 1998, p. 54.

${ }^{14}$ ART en la pell, p. 80, imagem 78; (EL) ARTE en la piel, p. 79.

15 "Sur un type de reliure des temps almohades". Ars Islamica I (1934), p. 80; (AL-)ANDALUS, pp. 123 e 308.

16 EXPOSICIÓN de encuadernaciones españolas, siglos XII al XIX. Madrid: Sociedad Española de Amigos del Arte, 1934, pp. 10, 23 e 35; PASSOLA, José M. - Artesania de la piel. Encuadernaciones en Vich, siglos XII-XV. Vic: Colomer Munmany, 1968, imagens 28, 30, 34 e 36; ÁLVARO ZAMORA, María Isabel; MONDINGORRA LLAVATA, María Luz; GIASANTE, Donatella - Els vestits del saber. Enquadernacions mudèjars a la Universitat de València. Valência: Universitat de València, 2003, pp. 27, 31, 58, 83, 85, 91, 93 e 99; CARPALLO-BAUTISTA, Antonio - "Las encuadernaciones mudéjares de
} 
encordoados, polígonos estrelados e entrançados apresentam-se nas duas manifestações. Tecnicamente falando, os guadamecis são pintados a óleo sobre um fundo de folha de prata, seguindo-se a leve texturação com punções; o couro utilizado é o de carneiro. Já as encadernações têm motivos vincados no couro de bezerro ou cordovão, seguidos de suave puncionamento a frio ou com ferros aquecidos, por vezes com apontamentos de folha de ouro. Ora os estofos em causa são em couro bovino de $6 \mathrm{~mm}$, com recurso a goiva em $\mathrm{V}$ cortante, e parcas punções em curva, ou em granulado para o campo, levando a um lavrado profundo e visível; são posteriores à época áurea das encadernações espanholas e dos guadamecis ibéricos.

A datação dos objectos enumerados e, em particular, a sua estética, não ajudam muito no entendimento global das gravuras mudéjares portuguesas, aqui consideradas. Só uma análise detalhada destes couros lavrados, a par de paralelismos com peças já incluídas na arqueologia medieval, e outras obras do mundo antigo, é que permite clarear dados, abrir portas e perceber a viagem que contêm.

\section{Os correeiros, estofadores de cadeiras em couro lavrado}

Em 1545, uma acta da vereação do Porto refere a necessidade em elaborar novas taxas, "por quanto a carestia em todallas cousas hia em tamanho crecjmento que era necesario prouer a jsso" 18 . Quanto aos "coreyros d obra grosa", a listagem inicia-se pelas peças de mobiliário de assento; estes artífices estofavam diversos tipos de cadeiras: "d espalldas das mayores", "d espalldas chãas e meaãs", "d espalldas menores", "de barrotes sem espaldas", "Rasa das mayores acustumadas", "Rasa e das menores", e "dobradiças nouamente emvemtadas" ${ }^{19}$. São sete modelos, e o facto de terem estofos em "couro laurado" mostra como este material está indissoluvelmente ligado ao mobiliário português de assento, pois não há referências ao uso de tecidos (sedas, veludos). Tendo

lacerías, tipo «toledano» y «salmantino», en la Catedral de Toledo". Al-Qantara XXXIII/2 (julioseptiembre 2012), pp. 375-404; ÁLVARO ZAMORA, María Isabel - "Encuadernaciones mudéjares". Artigrama 23 (2008), pp. 445-481.

${ }^{17}$ (EL) ARTE en la piel, pp. 27 e 78; GUADAMASSILS antics a Catalunya / Guadamecíes antiguos en Cataluña / Ancient Gilt Leather in Catalonia. Vic: Museu de l'Art de la Pell / Ayuntament de Vic, 2001, pp. 23 e 41; PEREIRA, Franklin - "Identidade e memória", p. 208.

${ }^{18}$ CRUZ, António - Os mesteres do Porto. Porto: Imprensa Industrial Gráfica, 1943, p. XCV.

${ }^{19}$ CRUZ, António - Os mesteres do Porto, pp. CV-CVI. 
em atenção a qualidade dos lavrados, é de considerar que havia correeiros especializados na gravura, ou, pelo menos, dedicando-lhe muito tempo, em detrimento da manufactura dos artefactos mais correntes.

O regimento lisboeta dos correeiros, de 1572, refere apenas a "cadeira de espaldas" como peça de exame, entre outros artefactos típicos do ofício. Noutro item estão referidas "as cadeiras de qualquer sorte" 20 , que não devem ser entendidas como obras da livre criação dos artífices envolvidos no seu fabrico. Aliás, é o regimento dos carpinteiros, também da mesma data, que esclarece haver modelos oficiais e medidas estabelecidas, em depósito na câmara municipal, e marcadas com a "marca da cidade"; ao afirmar "como erão antigamente" e "que se costumão fazer" ${ }^{21}$ para essas peças, o texto revela a antiguidade desses modelos, devedores aos seus congéneres tardo-medievais.

Já publiquei uma série de desenhos que mostram a evolução da cadeira, do século $\mathrm{X}$ ao século XVI ${ }^{22}$; algumas imagens dizem respeito à cadeira espanhola ("sillón frailero") 23 , que, estruturalmente, é muito semelhante à congénere portuguesa da mesma época; aliás, uma dessas imagens apresenta o espaldar em couro, cravado com tachas; já as outras duas têm, parece, o espaldar em tecido.

\section{Os elementos lavrados nas oito peças do Porto}

Este elencar de estéticas mostra como a arte mudéjar no couro se apoia em motivos antigos, antecedendo o mais usual do mudéjar ibérico, como os polígonos estrelados, enlaçados e entrançados. O paralelismo estético com outras peças salienta o seu papel de embaixadores de cultura; sendo em grande parte objectos de fácil transporte no comércio, tornavam mais simples a difusão de modos de ornamentrar, enraizados no património e visão do mundo. Encadernações, iluminuras, sedas, adargas, caixas em

\footnotetext{
${ }^{20}$ LIVRO DOS REGIMENTOS dos officiaes mecânicos da mui nobre e sempre leal cidade de Lisboa (1572). Ed. e prefácio por Virgílio CORREIRA. Coimbra: Imprensa da Universidade, 1926, p. 88.

${ }^{21}$ LIVRO DOS REGIMENTOS, pp. 115, 117 e 118.

22 PEREIRA, Franklin - O couro lavrado no Museu Municipal de Viana do Castelo: da arte "mourisca" à época barroca. Viana do Castelo: Museu Municipal, 2000, pp. 22 a 27.

23 ARIÉ, Rachel - Miniatures hispano-musulmanes: recherches sur un manuscrit arabe illustré de l'Escurial. Holanda: E. J. Brill, 1969, pranchas XVIII, XXI e XXXV; PEREIRA, Franklin - As cadeiras em couro lavrado, pp. 232 e 233.
} 
marfim esculpido, bolsas, tapeçarias, guadamecis, bainhas ou cerâmicas moviam-se nas redes comerciais, carregando os ornamentos da identidade cultural.

Quanto às ferramentas, bastava uma goiva em "v" cortante, e punções/cinzéis nãocortantes em duas ou três curvas (e o necessário martelo) para executar estas gravuras mudéjares; por vezes são acompanhadas por punções em pequeno círculo, e outra de meia-lua riscada. Eram ferramentas leves, que cabiam num pequeno saco, longe ainda da cinzelagem e aumento considerável de punções diversas nos lavrados renascentistas e barrocos posteriores, e que deram fama além-fronteiras à cadeira portuguesa. Provavelmente, estas oficinas trabalhavam sobretudo em Lisboa e não funcionavam em regime de itinerância.

\section{a) Triângulos obtidos por justaposição de curvas realizadas por cinzel não- cortante}

Os estofos $\mathrm{n}^{\mathrm{o}} \mathrm{s} 2$ a 8 apresentam curvas cinzeladas, assentes nas linhas-limite da moldura, à esquerda e à direita, formando triângulos escalonados. Os triângulos em patamares encontram-se já na arquitectura e artes móveis pré-islâmicas médioorientais $^{24}$, que chegaram a influenciar a arte grega ${ }^{25}$. As conquistas e expansão do império islâmico levaram à absorção deste motivo. Daí se encontrar tais elementos presentes, por exemplo, no Palácio omíada de Khirbat al-Mafjar, na Palestina, construído na primeira metade do século VIII ${ }^{26}$. Encontram-se também tais ameias na cidade palatina de Madinat' al-Zahra, e na Mesquita de Córdova ${ }^{27}$, que a antecede. O mesmo tipo de triângulo ou "espiga" continuou na azulejaria hispano-muçulmana, presente no Palácio de Alhambra e em edifícios mudéjares. O pequeno "ferro" de espiga mantém-se entre os últimos gravadores de couro de Granada - punção esta denominada "pino" - e encontra-se em raros estofos renascentistas portugueses; reapareceu na época do revivalismo de inícios do século XX em Portugal.

\footnotetext{
${ }^{24}$ CRESWELL, K. A. C. - Early Muslim Architecture. Umayyads. A. D. 622-750. Oxford: Claredom Press, II, 1969, p. 389; ASIA, ruta de las estepas: de Alejandro a Gengis Khan. Barcelona: Fundación La Caixa, 2001, p. 77.

${ }^{25}$ YON, Jean-Baptiste - "La época grecoromana - fusión de culturas bajo la impronta helenística". in Oriente Próximo - Historia y Arqueología. Colónia: Konemann, 2000, p. 81.

${ }^{26}$ HAMILTON, R. W. - Khirbat al-Mafjar, pp. 99, 102 e 182.

27 PAVÓN MALDONADO, Basílio - El arte hispano-musulmán en su decoración floral. Madrid: Agencia Española de Cooperación Internacional, 1990, tabla III-12-100 e XXI-61-413; PEREIRA, Franklin - O couro lavrado no Museu Municipal, p. 45.
} 
Formados por cravos de cabeça tronco-crónica, tais triângulos são usuais nas selas tradicionais portuguesas. A explicação que os artífices me deram para tal decoração é exactamente essa: é tradicional ser assim. Eventualmente, tal simplismo poderá esconder algo mais, enraizado na herança islâmica. As selas portuguesas são devedoras ao tipo de equitação denominado “à gineta”, identificado com os exércitos andalusís desde o século X. Escritos entre 971 e 975, os relatos palacianos do califa al-Hakam II parecem dar uma explicação plausível para os cravos tradicionais da selaria portuguesa. Alguns relatos referem cavalos com selas e arreios com a marca do Califato; outros especificam que a sela e o arreio estão adornados de prata, ou são os equinos provenientes das cavalariças do Califato ${ }^{28}$. A distinção entre arreios "civis" e califais deveria fazer-se por estes terem marcas estéticas específicas. Tem toda a lógica admitir que tal decoração se apresentaria na face exterior dos arções. Deste modo, os triângulos cravados nas selas portuguesas têm uma origem centenária e são uma manifestação de uma provável obrigação tornada tradição, aqui em selaria, e que se manteve após a Reconquista.

\section{b) Flor quadripétala sobre quadrado}

Seguimos para outro elemento, agora floral - representando a união entre o Céu e a Terra -, colocado no centro do assento da cadeira $n^{\circ} 2$. Outros dois assentos, mais "puros" no seu arcaísmo de linhas califais ibéricas, nos museus dos Patudos e Municipal de Viana do Castelo, repetem o motivo entre o entrançado floral da moldura ${ }^{29}$. Este pequeno motivo - flor quadripétala com cantos entre cada pétala, como se estivesse assente sobre um quadrado - parece ser o ornamento com mais longa vida.

Nos primeiros séculos da era cristã, a produção têxtil do Egipto copta atingiu grande qualidade, onde se incluía este motivo ${ }^{30}$. Com ligeiras variantes - com cinco cantos, ou enlaçado em si, e também a elementos iguais, mas com as pétalas transformadas em

\footnotetext{
${ }^{28}$ AL-RASI, Isa Ibn Ahmad - Anales Palatinos del Califa de Córdoba al-Hakam II, 360-361 H. - 971 975 J. C. Madrid: Sociedad Estudios y Publicaciones, 1967, pp. 63, 68, 166 e 167; PEREIRA, Franklin "Uma leitura do painel "Santiago aos Mouros" do Museu de Arte Sacra de Mértola - a equitação medieval e os artefactos da guerra a cavalo". Arqueologia Medieval 12 (Outubro 2012), p. 288.

${ }^{29}$ PEREIRA, Franklin - O couro lavrado no mobiliário artístico de Portugal. Porto: Lello e Irmão, 2000, p. 12; PEREIRA, Franklin - O couro lavrado no Museu Municipal, p. 43; PEREIRA, Franklin - "Couros artísticos nos interiores abastados de Arraiolos e Montemor-o-Novo, no século XVII". Almansor 1-2 série (2002), pp. 145-168; PEREIRA, Franklin - "Couros artísticos nos interiores abastados", p. 156.

${ }^{30}$ KYBALOVÁ, Ludmila - Les tissus coptes. Paris: Cercle d’Art, 1967, p. 13.
} 
círculo colocado sobre os lados do quadrado -, encontra-se tal módulo na escultura arquitectónica do já referido palácio de Khirbat al-Mafjar ${ }^{31}$; com o canto do quadrado virado para o interior, repete-se noutro padrão nesse palácio ${ }^{32}$. A mesma dinastia, agora limitada ao al-Andalus, utilizou a flor quadripétala enlaçada nos estuques e pedras de Madinat al-Zahra ${ }^{33}$, entre outros exemplos. Algumas plantas de edifícios islâmicos têm esta forma ${ }^{34}$.

Numa placa ornamental de Lisboa, as grandes flores quadrilobadas, também com os cantos do quadrado colocados entre cada pétala, mostram que estavam esculpidas internamente com águias; no topo, vê-se as garras e cauda da ave, e, na base, aparece ainda uma cabeça. Segundo Manuel Luís Real, em ficha de catálogo, essa placa repete desenhos dos estuques do palácio de Khirbat al-Mafjar, e "Não têm qualquer paralelo com a restante arte peninsular, atribuível à época visigótica" 35 ; o autor atribui esta placa a uma oficina moçárabe de Lisboa islâmica dos séculos IX-X. Tanto a flor quadripétala como a palmeta (também presente neste relevo, em grupos de quatro) - que veremos adiante - são motivos que aparecem nestes couros lavrados mais antigos. Contendo figuras, tal módulo - com menor ênfase dada aos meios-círculos / pétalas - encontra-se em iluminuras do "Apocalipse do Lorvão", de $1189^{36}$. A mesma forma utilizada no couro lavrado encontra-se talhada em madeira na cabeceira do túmulo de Isabel de Aragão, c. 1330, na Igreja de Sta. Clara (Coimbra); os cantos entre as pétalas apresentam-se agudos ${ }^{37}$. No Mosteiro da Batalha, do século XIV final, na fachada do portal sul, duas flores quadripétalas, no gablete triangular, encerram a heráldica dos reis D. João I e D. Filipa.

\footnotetext{
${ }^{31}$ HAMILTON, R. W. - Khirbat al-Mafjar, p. 199.

${ }^{32}$ HAMILTON, R. W. - Khirbat al-Mafjar, p. 184.

${ }^{33}$ PAVÓN MALDONADO, Basílio - "La formación del arte hispanomusulmán: hacia un corpus de la ornamentación geométrica rectilínea”. Al-Andalus XXXVIII-1 (1973), pp. 195-242, tabla XIII.

${ }^{34}$ STIERLIN, Henri - Islão. de Bagdade a Córdova: a arquitectura primitiva do século VII ao século XIII. Colónia: Tachen, 2002, p. 81.

${ }^{35}$ PORTUGAL ISLÂMICO: os últimos sinais do Mediterrâneo. Lisboa: Museu Nacional de Arqueologia / Instituto Português de Museus, 1998, pp. 86 e 87.

36 EGRY, Anne de - Um estudo de "O Apocalipse do Lorvão" e a sua relação com as ilustrações medievais do apocalipse. Lisboa: Fundação Gulbenkian, 1972, pp. 101-102; PEREIRA, Franklin - $O$ couro lavrado no Museu Municipal, p. 51.

${ }^{37}$ PEREIRA, Paulo - História da arte em Portugal. Vol. I. Lisboa: Círculo de Leitores, 1995, p. 443.
} 
O recurso a tal desenho continuou na arte mudéjar de Toledo, Tordesilhas e Sevilha; neste último caso, cada módulo encerra silhuetas com cenas da corte e de cavalaria ${ }^{38}$. $\mathrm{Na}$ azulejaria andalusí do século XIII-XIV, presente no Museu Arqueológico de Córdova, as cenas internas de medalhões entrançados do século XIII-XIV incluem também animais, cavaleiros, e aspectos dos sentidos do gosto, olfacto e ouvido ${ }^{39}$. Encontra-se tal módulo (composto por duas variantes, pintadas alternadamente) na moldura interna definindo dois arcos contra-curvados encerrando uma pinha, num frontal de altar do século XVI, em guadameci (com o pano central pintado com um Cristo recebendo a pomba branca do Espírito Santo), no Museu Abade de Baçal (inventário $\left.\mathrm{n}^{\mathrm{o}} 147\right)^{40}$. O mesmo módulo foi utilizado num padrão de dois guadamecis tradicionais ibéricos - motivos pintados, puncionamento com ferros clássicos -, presentes no Museu de l'Art de la Pell (Vic), e datáveis do século XVI ${ }^{41}$; o tamanho grande deste padrão afasta estes dois guadamecis daquele de estética mudéjar, na colecção do museu brigantino. No século XVI-XVII português continuava-se a recorrer a outras versões da flor quadripétala em azulejos de parede, como ainda se pode ver em várias igrejas. Na escultura arquitectónica, já dos séculos XVII-XVIII, o mesmo módulo foi utilizado, seja de um modo austero (em fontes), seja com todo o tratamento floral barroco, como molduras de janelas. Num outro livro já publiquei uma série de desenhos relativos a este módulo, e às viagens subjacentes ${ }^{42}$ e já abordei mais extensamente o tema num artigo ${ }^{43}$. No século XX, encontram-se exemplos na azulejaria e ferro, de produção industrial massificada.

\section{c) Moldura larga e com motivos florais inscritos em SS}

O recurso a estas molduras tão arcaicas parece basear-se na facilidade em utilizar um modelo mais que corrente, um esquema "pronto a usar", apenas necessitando de ajustes

\footnotetext{
38 PAVÓN MALDONADO, Basílio - Arte toledano: islámico y mudéjar. Madrid: Instituto Hispanoárabe de Cultura, 1988, lâmina CLXXIII.

39 TORRES BALBÁS, Leopoldo - "De cerámica hispano-musulmana". Al-Andalus IV (1939), pp. 421 e 422.

${ }^{40}$ PEREIRA, Franklin - "Identidade e memória", p. 209.

${ }^{41}$ ART EN LA PIEL, pp. 81 e 95.

42 PEREIRA, Franklin - O couro lavrado no Museu Municipal, pp. 50-53.

${ }^{43}$ PEREIRA, Franklin - "A grande viagem da flor quadripétala: um estudo a partir da fíbula da escultura “Nossa Senhora do Ó” do Museu Municipal Carlos Reis/Torres Novas”. Nova Augusta 24 (2012), pp. 183-196.
} 
para preencher as quatro faixas/lados do estofo. Com o avançar do Renascimento, estas molduras arcaicas serão substituídas pela fileira de folhas estilizadas de acanto.

Nas peças $\mathrm{n}^{\circ} \mathrm{s} 2,3,4$ e 5, a moldura floral estilizada tem como estrutura uma espiral ou $\mathrm{S}$, havendo, por vezes, um ponto de união das curvas simétricas, constituído por um anel, argola ou fivela ("hebilla", em espanhol) ${ }^{44}$. Denominadas em inglês "scroll patterns", aparecem como bordas internas de vasos cerâmicos de Bizâncio; quanto à sua proveniência, "it is hard to be certain of origins, the pattern being so universal. (...) Sometimes they were stylized into what are little more than undulating bands, but when they are elaborate they usually take on a form which suggests relationships with Islamic pottery" ${ }^{45}$. Relativamente ao emprego deste tipo de molduras na arte ibérica, B. Pavón Maldonado afirma: "La cenefa estrecha con palmetas asidas a roleos ondulados encuentra ya ampla acogida en el arte sasánida, el bizantino e en el omeya oriental; se impone sobre todo en Madinat al-Zahra y en la Mesquita de Córdoba"46.

Assim, este tipo de moldura tem paralelos com outras, presentes tanto na arquitectura islâmica do Médio Oriente omíada e abássida ${ }^{47}$ como na peninsular, em Madinat al$Z_{\text {Zahra }}^{48}$ (à qual não falta o vinco interno) e na Mesquita de Córdova ${ }^{49}$; nas artes móveis, encontra-se, por exemplo, numa arqueta de marfim da época Taifa ${ }^{50}$, numa lápide funerária do século XII, em território português ${ }^{51}$, e em iluminuras dos "Beatos" espanhóis.

\section{d) Folha de acanto, estilizada em gomos e anéis}

$\mathrm{Na}$ CMGJ, esta estilização aparece no minucioso lavrado da peça $\mathrm{n}^{\circ} 1$, com semicírculos assentes na borda das folhas. De novo, convoco a arte islâmica peninsular,

${ }^{44}$ PAVÓN MALDONADO, Basílio - Arte toledano, p. 225.

${ }^{45}$ RICE, David Talbot - "The pottery of Bizantium and the Islamic world". in Studies in Islamic Art and Architecture in Honour of Professor K. A. C. Creswell. Cairo: The American University in Cairo Press, 1965, p. 206.

${ }^{46}$ PAVÓN MALDONADO, Basílio - El arte hispano-musulmán, p. 111.

${ }^{47}$ ANDALOUSIES. de Damas à Cordoue. Paris: Institut du Monde Arabe / Hazam, 2000, pp. 27 e 28.

48 PAVÓN MALDONADO, Basílio - El arte hispano-musulmán, lâmina XII-26, $\mathrm{n}^{\circ}$ 222; (EL) ESPLENDOR de los omeyas cordobeses. La civilización musulmana de Europa Occidental. Madinat alZahra: Fundación El Legado Andalusí / Junta de Andalucia, 2001, p. 139.

49 BARRUCAND, Marianne; BEDNORZ, Achim - Arquitetura islámica en Andalucía. Colónia: Taschen, 1992, p. 57.

${ }^{50}$ (AL-)ANDALUS, p. 249.

${ }^{51}$ PORTUGAL ISLÂMICO, p. 249. 
na busca de uma explicação para tal estética: a folha com anéis intercalados nos gomos - denominada em estudos espanhóis como "palmeta digitada"52 - aparece em marfins califais e nos estuques de Madinat al-Zahra ${ }^{53}$, nos primeiros anos do século XI; o seu uso prolongou-se na arte dos reinos de Taifas $^{54}$. As épocas almorávida ${ }^{55}$ e almóada ${ }^{56}$ levaram o acanto a maior estilização; por vezes, a folha é reduzida a gomos intercalados com anéis, ou preenchida com estilizações florais. O seu uso prolongou-se nas produções nazarís ${ }^{57}$; aparece também na Sinagoga de Santa Maria la Blanca (Toledo), do século XIII ${ }^{58}$, denotando o prolongamento da estética califal na comunidade judaica, e, ainda, na ornamentação cristã elaborada por mudéjares, como no Mosteiro de las Huelgas, em Burgos ${ }^{59}$, do mesmo século.

Outra série de desenhos, ilustrando o desenvolvimento desta estilização "aos gomos e anéis", encontra-se num artigo que volta a focar o Mosteiro de las Huelgas ${ }^{60}$. Considera o autor ainda exemplos da Mesquita de Córdova, Madinat al-Zahra, da arte almorávida (em Almeria, Fez e Tremecén), na Mesquita do Cairo, terminando na produção mudéjar (onde sobressaem os estuques do claustro do Mosteiro de las Huelgas, já referido).

Tendo permanecido sete séculos na Península, esta estilização, a nível dos couros de arte, apenas se encontra nos lavrados portugueses, com diversos aspectos decorrentes da sua génese sob o Califato.

Aos desenhos já publicados ${ }^{61}$, mostrando a evolução da tão corrente folha de acanto, até se estilizar em "palmeta digitada", haverá que acrescentar o exemplo português aqui

\footnotetext{
${ }^{52}$ PAVÓN MALDONADO, Basílio - El arte hispano-musulmán, p.115.

${ }^{53}$ TORRES BALBÁS, Leopoldo - “"Las yeserías descubiertas recientemente en las Huelgas de Burgos”. Al-Andalus VIII (1943), pp. 209-254.

${ }^{54}$ TORRES BALBÁS, Leopoldo - "Las yeserías descubiertas".

${ }^{55}$ RICARD, Prosper - Pour comprendre l'art musulman dans l'Afrique du Nord et d'Espagne. Paris: Hachette, 1924, p. 170, figuras 303 e 304.

${ }^{56}$ RICARD, Prosper - Pour comprendre, figuras 305-312.

${ }^{57}$ RICARD, Prosper - Pour comprendre, figuras 317-320.

${ }^{58}$ TORRES BALBÁS, Leopoldo - "Las yeserías descubiertas", p. 224; PAVÓN MALDONADO, Basílio - Arte toledano, pp. 81 e 136.

${ }^{59}$ PAVÓN MALDONADO, Basílio - Arte toledano, pp. 124 e 125.

${ }^{60}$ TORRES BALBÁS, Leopoldo - "Las yeserías descubiertas", p. 215.

${ }^{61}$ PAVÓN MALDONADO, Basílio - El arte hispano-musulmán, tabla XXI, no 43, p. 121; PEREIRA, Franklin - O couro lavrado no Museu Municipal, p. 57; PEREIRA, Franklin - "Identidade e memória", p. 213.
} 
referido, que ombreia com semelhantes desenvolvimentos, presentes em estofos da mesma época e tradição ${ }^{62}$, estofos esses nos museus de Soares dos Reis ${ }^{63}$, dos Patudos e de Artes Decorativas de Viana do Castelo ${ }^{64}$, na Igreja de Santa Eufémia de Chancelaria (Torres Novas) ${ }^{65}$ e numa colecção particular do Porto ${ }^{66}$.

\section{e) Rameado com palmetas em quadro direcções, saindo de um centro}

Este caso apresenta-se no assento da peça $n^{\circ} 2$; os quatro braços poderão ser invocações dos quatro rios do paraíso muçulmano. A palmeta, com um anel na base, encontra-se esculpida em estuque no palácio de Khirbat al-Mafjar; quatro palmetas, apontando a um centro, formam uma roseta ou, em linha, formam outro padrão ${ }^{67}$. Em mosaico, aparece na Mesquita de Córdova e, noutros materiais, em Madinat al-Zahra ${ }^{68}$; prolongou-se na época taifa ${ }^{69}$, almorávida e almóada, e permaneceu na arte do Sultanado de Granada ${ }^{70}$.

Atrás, referi o módulo da flor quadripétala sobre quadrado, presente num relevo lisboeta do século X-XI; um outro também apresenta palmetas, organizadas como que nas diagonais de um quadrado, e que terá, como os outros do relevo citado, a "sua filiação em paralelos de origem oriental, como os de Khirbat al-Mafjar (739-743), transmitidos por artistas do período omíada à Península Ibérica, talvez no tempo de Abd al-Rahman I"71.

Uma outra versão, mais requintada, aparece pintada em cerâmica islâmica atribuída aos séculos XI-XII, descoberta em Mértola ${ }^{72}$ : quatro ramos iguais saindo do enlaçado têm paralelos com o centro do assento em causa.

\footnotetext{
${ }^{62}$ PEREIRA, Franklin - O couro lavrado no Museu Municipal, pp. 59 e 60.

${ }^{63}$ PEREIRA, Franklin - "Identidade e memória", p. 212.

${ }^{64}$ PEREIRA, Franklin - O couro lavrado no Museu Municipal, pp. 43 e 44; PEREIRA, Franklin "Couros artísticos nos interiores", p. 156.

${ }^{65}$ PEREIRA, Franklin - "Identidade e marcas de cultura - a propósito de uma cadeira em couro lavrado na igreja de Santa Eufémia da Chancelaria (Torres Novas)”. Nova Augusta 21 (2009), pp. 143-153.

${ }^{66}$ PEREIRA, Franklin - O couro lavrado, pp. 36, 92 e 93.

${ }^{67}$ PEREIRA, Franklin - "Identidade e memória", p. 211; HAMILTON, R. W. - Khirbat al-Mafjar, p. 151, figura $114 \mathrm{a}$, p. 213.

68 PAVÓN MALDONADO, Basílio - El arte hispano-musulmán, lâmina I-5, no 47, e lâmina I-2, nº 6; BARRUCAND, Marianne; BEDNORZ, Achim - Arquitetura islámica, p. 78.

${ }^{69}$ (Al-)ANDALUS, p. 253.

70 PAVÓN MALDONADO, Basílio - El arte hispano-musulmán, tabla III, nº 19 e 26.

${ }^{71}$ REAL, Manuel Luís - "Os Moçárabes do Gharb português". in Portugal Islâmico: os últimos sinais do Mediterrâneo. Lisboa: Museu Nacional de Arqueologia / Instituto Português de Museus, 1998, p. 86.

${ }^{72}$ TORRES, Cláudio (org.) - Cerâmica islâmica portuguesa. Mértola: Câmara Municipal de Mértola / Fundação Gulbenkian / Campo Arqueológico de Mértola, 1987, imagem 76.
} 


\section{f) estilização floral com pequenos enrolamentos}

Este esquema arcaico encontra-se nas peças $n^{\circ} \mathrm{s} 2,3$ e 4; trata-se de pequenos enrolamentos, como que "caracóis"; tal modo de elaborar a estilização floral é semelhante ao que se encontra nos medalhões vegetalistas que acompanham alguns "suras", elaborados nas épocas Taifa, almorávida e almóada, no al-Andalus, séculos XI e XII ${ }^{73}$.

\section{g) campo floral trabalhado com minudência}

Saliente da peça $\mathrm{n}^{\circ} 1$ está o trabalho de grande minúcia do lavrado floral, com cinco pássaros. Remete para os marfins califais $^{74}$, relevando-se, de novo, as pequenas produções transportáveis como inspiradoras e transmissoras de estéticas. Repete-se numa cadeira semelhante, exposta no Museu de Pontevedra, com o espaldar cortado para caber na estrutura de madeira ${ }^{75}$, denotando que o estofador não teve apreço pelos couros lavrados; a moldura desta cadeira é em amplos SS, sendo outra variante mudéjar.

\section{h) moldura em duplo arco contrecurvado}

Este tipo de moldura, também único na peça n 1, foi empregue nos "panos d'armar" em tecido, e também em guadameci, tal como se vê nos exemplos espanhóis quinhentistas $^{76}$; com a mesma data, o já referido frontal de altar de Bragança recorre a este módulo nos dois "panos" laterais. Os guadamecis relevados nas colunas da charola do Convento de Cristo $^{77}$, de inícios do século XVI, mostram outro paralelismo para este padrão, enlaçado a folhagem gótica. A fachada do portal sul do Mosteiro da Batalha encimada pelos brasões dos reis, encerrados em flor quadripétala sobre quadrado, atrás referida - apresenta este padrão esculpido no espelho trilobado da porta, com filetes que se entrecruzam.

\footnotetext{
73 (AL-)ANDALUS, pp. 304-311.

74 (AL-)ANDALUS, pp. 191 a 204.

75 PEREIRA, Franklin - As cadeiras em couro lavrado, pp. 223, 230 e 231.

76 FERRANDIS TORRES, José - Cordobanes y guadamecíes: catálogo ilustrado de la exposición. Palácio de la Biblioteca y museos nacionales. Madrid: Sociedad Española de Amigos del Arte, 1955, imagens 49, 50 e 59; ART en la pell, pp. 80, 90 e 91; (EL) ARTE en la piel, p. 85.

77 PEREIRA, Franklin - "Os couros artísticos: modas e estéticas em trânsito". in Sphera Mundi - Arte e cultura no tempo dos Descobrimentos / Congresso Internacional. Lisboa, 13-15 Outubro 2015. Vale de Cambra: Caleidoscópio, 2015, pp. 297-312; PEREIRA, Franklin - "The Charola de Tomar: early 16th century mould-embossed gilt leather, glued to stone walls". Newsletter. Stroke-up-Trent: Archeological Leather Group 43 (Março 2016), pp. 14-16.
} 
Todas as peças aqui em estudo são réstias de um passado esquecido, da estética islâmica que permaneceu nestes modelos de cadeira "d espaldas". Acessível e resistente, o couro bovino tornou-se a matéria-prima ideal para estofos nos territórios que se tornaram Portugal, sendo de admitir que foi buscar os elementos lavrados a outras artes, ou mesmo aos correntes artefactos de couro (adargas, cintos, selas, aljavas, coxins e guadamecis) das modas mudéjares.

O "sillón frailero" do país vizinho, contemporâneo da cadeira "d'espaldas" portuguesa, mostra o couro bovino vincado com linhas paralelas às bordas (obtidas com um estilete de metal ou osso $)^{78}$ ou puncionado em pouca quantidade e variedade mas, na maioria dos casos, com pespontado em padrões geométricos simples ${ }^{79}$. Completamente distintos dos estofos simples da cadeira espanhola da mesma época, estes lavrados provam a especificidade portuguesa, enraizada no legado andalusí, que permaneceu no ocidente peninsular após a Reconquista, e durou até inícios do Renascimento.

\section{A participação de mudéjares e o trabalho do couro lavrado}

Várias questões fundamentais surgem perante este elencar de estéticas: como é que motivos tão antigos, antecessores daqueles mais usuais da arte mudéjar (vistos na encadernação mudéjar e em raros guadamecis), passam a ser os "oficiais" nas cadeiras encouradas? Quem eram esses correeiros-gravadores? Qual a participação de artífices mudéjares neste trabalho para a elite da época? Para responder, passo em revisão alguns tópicos relativos ao couro e à presença dos muçulmanos nos ofícios.

O regimento dos "borzeguyeyros çapateiros çoqueiros e chapineyros cortidores çurradores e odreyros", de 1489, é uma peça importante para clarear, a nível mesteiral, a

\footnotetext{
${ }^{78}$ PEREIRA, Franklin - "Leather decoration tools", p. 11.

${ }^{79}$ FEDUCHI, Luís - Historia del Mueble. Madrid: Afrodisio Aguado, 1946, figura 367; FEDUCHI, Luís - Antologia de la Silla Española. Madrid: Afrodisio Aguado, 1957, figuras 33, 37 e 45; GUILÓ ALONZO, Maria Paz - "Cordobanes y guadamecíes". in BONET CORREA, António - Historia de las artes aplicadas y industriales en España. Madrid: Editorial Cátedra, 1982, p. 326; AGUILÓ ALONZO, Maria Paz - El mueble clásico español. Madrid: Editorial Cátedra, 1987, p. 154; AGUILÓ ALONZO, Maria Paz - El mueble en España, siglos XVI-XVII. Madrid: Consejo Superior de Investigaciones Cientificas / Ediciones Antiqvaria, 1993, pp. 353-355; AGUILÓ ALONZO, Maria Paz - "Cordobanes y guadamaciles". in (EL) ARTE en la piel, p. 21; AGUILÓ ALONZO, Maria Paz - "Cordobanes y guadameciles". Madrid: Espasa Calpe. Summa Artis LXV (1999), pp. 266 a 268.
} 
participação dos artífices das "três religiões do Livro" no trabalho do couro; esse documento envolve os fabricantes da matéria-prima (curtidores e surradores), aqueles que manufacturam o utilitário sapato (em vários modelos) e os fabricantes de odres. Cristãos, judeus e mudéjares/"mouros" estão presentes no curtume e estabelecem regras para o uso de determinadas cores no calçado ${ }^{80}$; rectificado em 1532 , este documento tem uma muito explícita frase final: "tiramdo as palauras que falão nos Judeus e mouros pelos Ja hy não aver" ${ }^{81}$ - este é o reconhecimento da extinção das minorias judaica e muçulmana nos ofícios básicos do couro, a par de um final anteriormente oficializado: "O ciclo do mudejarismo português encerra-se a Dezembro de 1496 com a publicação do édito de D. Manuel"82. O surgir da cadeira encourada no século XVI afasta-nos das "vivências mistas" 83 nos ofícios; as referências da autora à participação dos mudéjares no calçado são do século XV, em Beja, Loulé, Avis e Évora; nesta última cidade, em finais do século XIV, vemos os "mouros çapateiros" 84 envolvidos também no curtume $^{85}$. O Livro dos Regimentos de 1572 refere que o oficial, no exame para mestre sapateiro de obra de vaca, realizava dois tipos de calçado: "abrochados Solados de correa e outros chãos solados aa mourisca" ${ }^{\text {86; }}$ neste último, empregava um método herdado dos sapateiros islâmicos. Na selaria, e ainda lendo o mesmo Livro dos Regimentos, continuava a fabricar-se o modelo de sela gineta, permanecendo, portanto, o tipo de monta à gineta herdado dos exércitos andalusís, a par da sela estradiota do norte cristão; o ofício de correeiro tinha anexo o de adargueiro - a adarga era o escudo de couro que protegia o cavaleiro da monta à gineta. Métodos de elaboração e apetrechos continuaram em uso no Portugal cristão, agora sem artífices mudéjares, mas antes por continuidades e provas da sua eficiência, seja no calçar ou no cavalgar.

Afastados do curtume e da utilidade do calçado, os correeiros, logo que a cadeira lavrada foi ganhando terreno face ao ocaso das modas de se sentar herdadas do Islão em estrados atapetados e coxins, muitas vezes em guadameci -, trouxeram para o estofo

\footnotetext{
${ }^{80}$ PEREIRA, Franklin - Ofícios do couro na Lisboa medieval. Lisboa: Editora Prefácio, 2009, p. 54.

${ }^{81}$ LIVRO das Posturas Antigas. Lisboa: Câmara Municipal de Lisboa, 1974, pp. 324 e 330.

82 BARROS, Maria Filomena Lopes de - Tempos e espaços de mouros: a minoria muçulmana no reino português (séculos XII a XV). Lisboa: Fundação Calouste Gulbenkian, 2007, p. 595.

${ }^{83}$ BARROS, Maria Filomena Lopes de - Tempos e espaços de mouros, p. 593.

${ }^{84}$ BARROS, Maria Filomena Lopes de - Tempos e espaços de mouros, p. 515.

${ }^{85}$ PEREIRA, Franklin - Ofícios do couro, p. 54.

${ }^{86}$ LIVRO DOS REGIMENTOS dos officiaes mecânicos da mui nobre e sempre leal cidade de Lisboa (1572). Ed. e prefácio por Virgílio CORREIRA. Coimbra: Imprensa da Universidade, 1926, p. 77.
} 
em couro grosso de bovino as estéticas da elite. Tal diversidade de motivos indicia haver uma possante produção anterior (popular e erudita), usando diversas matériasprimas, em aspectos decorativos semelhantes; era manufacturada pelas populações islâmicas e pelos mudéjares portugueses, sobrevivendo tais padrões ao desaparecimento e integração dos muçulmanos na sociedade cristã. Valem estes excelentes estofos para provar a continuidade da tradição artística, antes de ter sido remetida à produção de cariz popular (safões, sacos de pastores, cerâmica, chifre, madeira, cabaça, tecelagem), a partir do advento do Renascimento. Eclipsam os "couros de Córdova", um termo genérico onde se mescla cordovões, trabalho artístico e guadameci, pretendendo dar supremacia à capital do Califato como iniciadora das artes do couro ibérico; esta designação tem mais de nacionalismo do que fundamentação histórica, e é um mito, como comprovam estes couros lavrados portugueses ${ }^{87}$. Apesar de já ter abordado o assunto em seminário em Espanha ${ }^{88}$, ainda não vi estudos espanhóis que se debrucem sobre os lavrados mudéjares portugueses.

Tecnicamente falando, o uso da goiva em $\mathrm{V}$ cortante aparece também numa arca mudéjar do século XVI, da colecção da Escola de Artes e Ofícios de Córdova ${ }^{89}$; os motivos lavrados no grosso couro bovino - felinos em pé segurando ramagem, aves no interior de medalhões florais ou bicando frutos -, o uso do puncionamento (bola, curva, triplo V) no corpo dos animais e na texturação do fundo, e a imprecisão de mão no uso da goiva cortante, afastam esta arca das cadeiras mudéjares portuguesas.

Augusto Cardoso Pinto publicou uma série de imagens e comentários a quatro cadeiras estruturalmente semelhantes às da Casa-Museu Guerra Junqueiro ${ }^{90}$. Nenhum dos couros lavrados é, no entanto, em estilo mudéjar; uma das peças apresenta couros prensados ${ }^{91}$.

\footnotetext{
${ }^{87}$ PEREIRA, Franklin - "A arte dos pastores"; PEREIRA, Franklin - "O couro e o Islão na Península Ibérica: identidade cultural, pedagogia e património. Reflexões em torno de uma tese de mestrado". Ensinarte / Revista das artes em contexto educativo 10 (2007), pp. 22-33; PEREIRA, Franklin "Identidade e memória".

${ }^{88}$ PEREIRA, Franklin - "Las influencias del Califato de al-Andalus en los cueros labrados de Portugal del siglo XVI". in Mil años de trabajo del cuero. Actas del II Simposium de Historia de las Técnicas. Córdova: Sociedad Española de Historia de las Ciências y de las Técnicas / Universidad de Córdoba 2003, pp. 501-518.

${ }^{89}$ PEREIRA, Franklin - "Leather decoration tools", p. 10.

${ }^{90}$ PINTO, Augusto Cardoso - Cadeiras portuguesas. Lisboa: A. C. Pinto, 1952, estampas XIV, XV e XVII.

${ }^{91}$ PINTO, Augusto Cardoso - Cadeiras portuguesas, estampa XVII, figura 12.
} 
Este caso prova a raridade destes lavrados e a falta de conhecimentos do autor referido quanto às artes do couro, incluindo a do guadameci.

A par do frontal de altar do século XVI, em guadameci, no Museu Abade de Baçal ${ }^{92}$, já referido, e da produção alentejana de sacos de pastores e safões ${ }^{93}$, poderiam/deveriam estes estofos ter estado presentes nas exposições (e respectivos catálogos) "Memórias Árabo-islâmicas em Portugal" (realizada em Mértola em 1997) ${ }^{94}$ e "Portugal islâmico: os últimos sinais do Mediterrâneo" (realizada no Museu Nacional de Arqueologia em $1997-98)^{95}$

Servem também estes estofos para um fim mais vasto: "reequacionar as interacções entre a maioria cristã e a minoria islâmica (nomeadamente com o auxilio de outras ciências, que não apenas a História), o que permitirá perspectivar de forma mais correcta a realidade que chamamos «nação»" 96 . Uma nação que tem, no mobiliário de assento, a cadeira em couro lavrado como representante, uma particularidade europeia com fama. Mais do que as cadeiras renascentistas e barrocas, muito frequentes em museus e colecções particulares, estão estas peças cheias de História, e são janelas para um legado de riqueza e esplendor.

\section{Caracterização das peças em estudo}

Peça $n^{\circ} 1$ - cadeira da CMGJ

A moldura em duplo arco contracurvado destes lavrados relembra particularmente os "panos d'armar" de c. 1500 elaborados em guadameci, em Espanha e Portugal. Reparese, ainda, que a moldura contém, no interior de cada módulo, uma flor, que se aproxima ao arcaico desenho da flor quadripétala sobre quadrado. Vê-la-emos claramente no centro do assento (figura $\mathbf{2 A}$ ).

\footnotetext{
92 PEREIRA, Franklin - "Identidade e memória", p. 209.

93 PEREIRA, Franklin - "A arte dos pastores do sul peninsular"; PEREIRA, Franklin - "O couro e o Islão"; PEREIRA, Franklin - "Identidade e memória".

94 PEREZ, Rosa Maria (org.) - Memórias árabo-islâmicas em Portugal. Lisboa: Comissão Nacional para a Comemoração dos Descobrimentos Portugueses, 1997.

95 PORTUGAL ISLÂMICO.

96 BARROS, Maria Filomena Lopes de - A comuna muçulmana de Lisboa: sécs. XIV e XV. Lisboa: Hugin, 1998, p. 165.
} 
Estamos perante um motivo partilhado entre a tradição mudéjar dos "panos d'armar" (seja em têxtil, seja em guadameci) e uma linhagem a emergir, a do mobiliário de assento, onde o couro bovino era a matéria-prima dominante em Portugal; esta linhagem absorveu, na sua estética, motivos arcaicos, sendo o padrão de arcos duplos contracurvados um dos pouquíssimos elementos partilhados. O interior do espaldar (figura 1A) relembra os marfins califais ${ }^{97}$; apresenta delicadas ramagens, onde se encontram cinco aves diferentes, a maior das quais parece ser um pavão; alguns ramos têm pequenas curvas sobre o enrolamento, sugerindo ser continuidade da estilização do acanto no al-Andalus califal ${ }^{98}$. Para a execução de tanto detalhe, o correeiro utilizou, além da goiva em "v" cortante ou da faca de incisão - este é um caso em que a finura das linhas cria dúvidas sobre o tipo de ferramenta -, uma punção minuciosa (denominada "escama" pelos gravadores actuais) para criar o efeito de penas nos pássaros. Como novidade, há um riscado obtido por punção, que dá a ideia de rebaixamento e sobreposição, e que iria passar a ser corrente nas gravuras renascentistas posteriores. O correeiro utilizou ainda um "fosco"/granulado para o fundo, como era típico desde o Gótico peninsular.

O assento (figura 1B) repete a moldura do espaldar; o seu centro, no entanto, parece ser uma evolução a partir dos modelos califais das palmetas distribuídas em quatro direcções. A estilização floral que rodeia o centro deste assento - quatro folhas nas diagonais, enrolamentos e faixas - repete-se em dois outros da FGJ, soltos da estrutura, que veremos adiante (peças $n^{\circ}$ s 7 e 8). Pela negativa, note-se que a pregaria, que fixa $o$ espaldar, atropela a moldura; aconteceria o mesmo na estrutura original?

O Museu de Pontevedra possui uma cadeira recente, de estrutura simples; o espaldar repete o mesmo lavrado desta peça da CMGJ, e não faz par com o assento. A sua moldura baseia-se no antigo motivo das ondas, ou largos SS deitados (que veremos nos assentos $\mathrm{n}^{\mathrm{o}} 7$ e 8); o espaldar foi cortado, denotando que o marceneiro ou o estofador nada percebia de couros artísticos e procurou, com o beneplácito do proprietário, tornar

\footnotetext{
${ }^{97}$ FERRANDIS TORRES, José - Marfiles árabes de Occidente, siglos X y XI. Vol. I e II. Madrid: Estanislao Mestre, 1935-1940; (AL-)ANDALUS, pp. 191 a 204; ANDALOUSIES, pp. 122 e 123.

${ }^{98}$ PAVÓN MALDONADO, Basílio - El arte hispano-musulmán, p. 121, tabla XXI, nº 43; PEREIRA, Franklin - O couro lavrado no Museu Municipal, pp. 59 e 60.
} 
a cadeira funcional ${ }^{99}$. Apesar deste corte, este espaldar adiciona mais dados à produção, rara e magnífica, desta "tenda" de correeiros, com um peculiar método de gravura minuciosa, possivelmente herdado das anteriores oficinas de mudéjares portugueses (se não de sangue, pelo menos de tradição cultural erudita). Permite também este espaldar considerar as trocas comerciais com a Galiza no século XVII e XVIII, aspecto que também foquei no estudo citado, publicado pelo Museu de Pontevedra ${ }^{100}$.

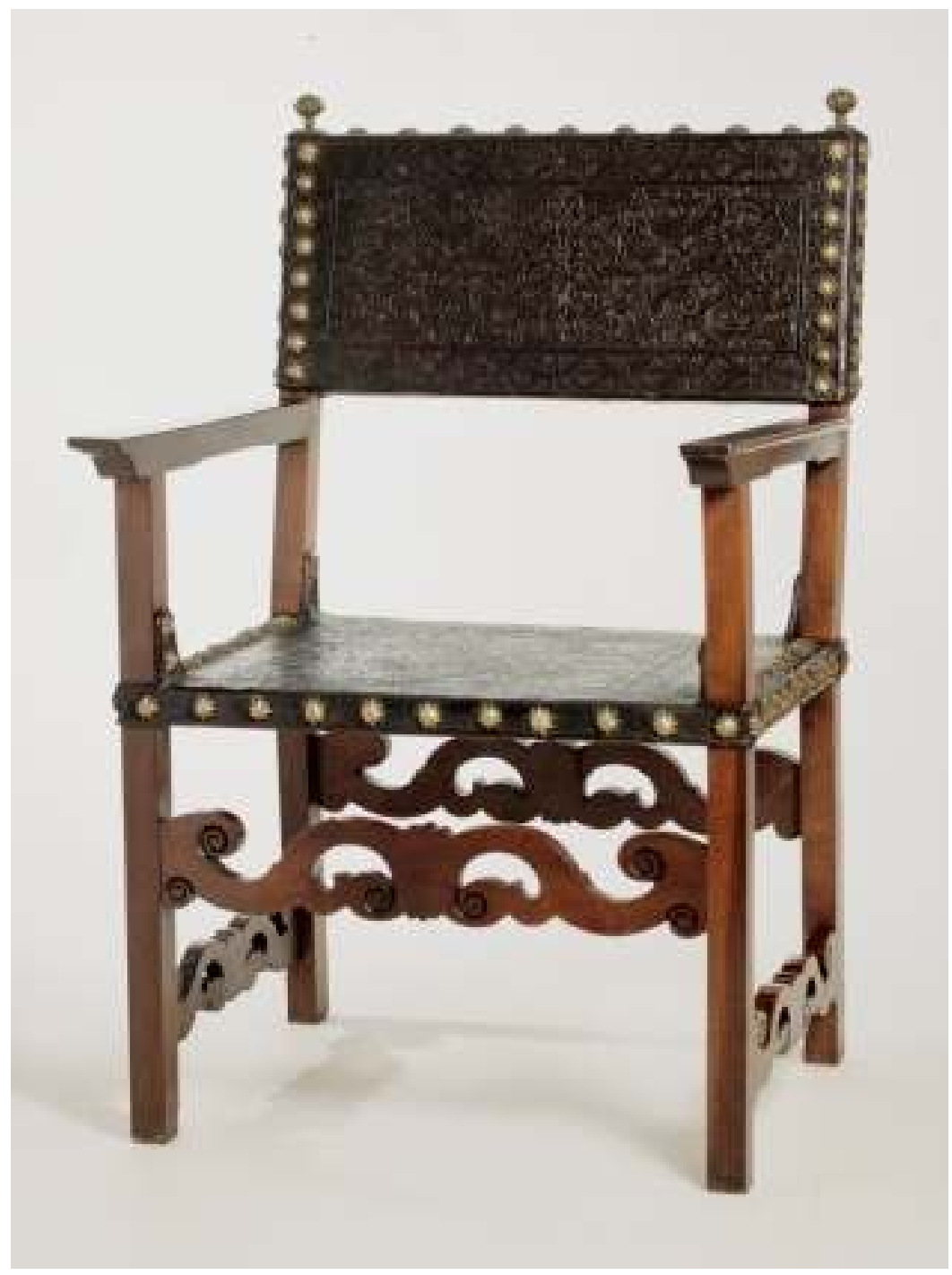

Figura 1 - Cadeira da CMGJ.

\footnotetext{
${ }^{99}$ PEREIRA, Franklin - As cadeiras em couro lavrado, pp. 223, 230 e 231.

${ }^{100}$ PEREIRA, Franklin - As cadeiras em couro lavrado, pp. 240 a 242.
} 


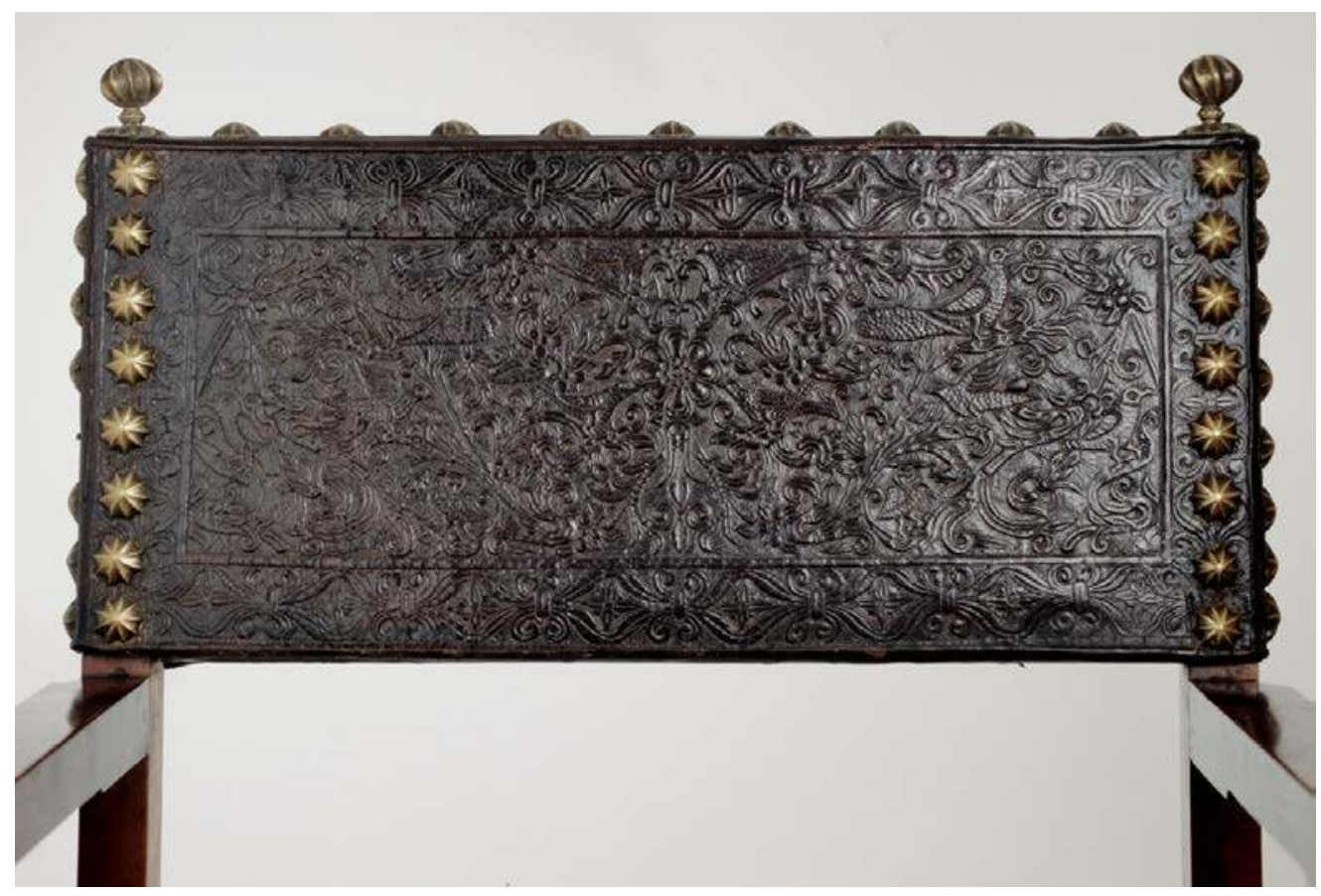

Figura 1A - Espaldar de cadeira da CMGJ.

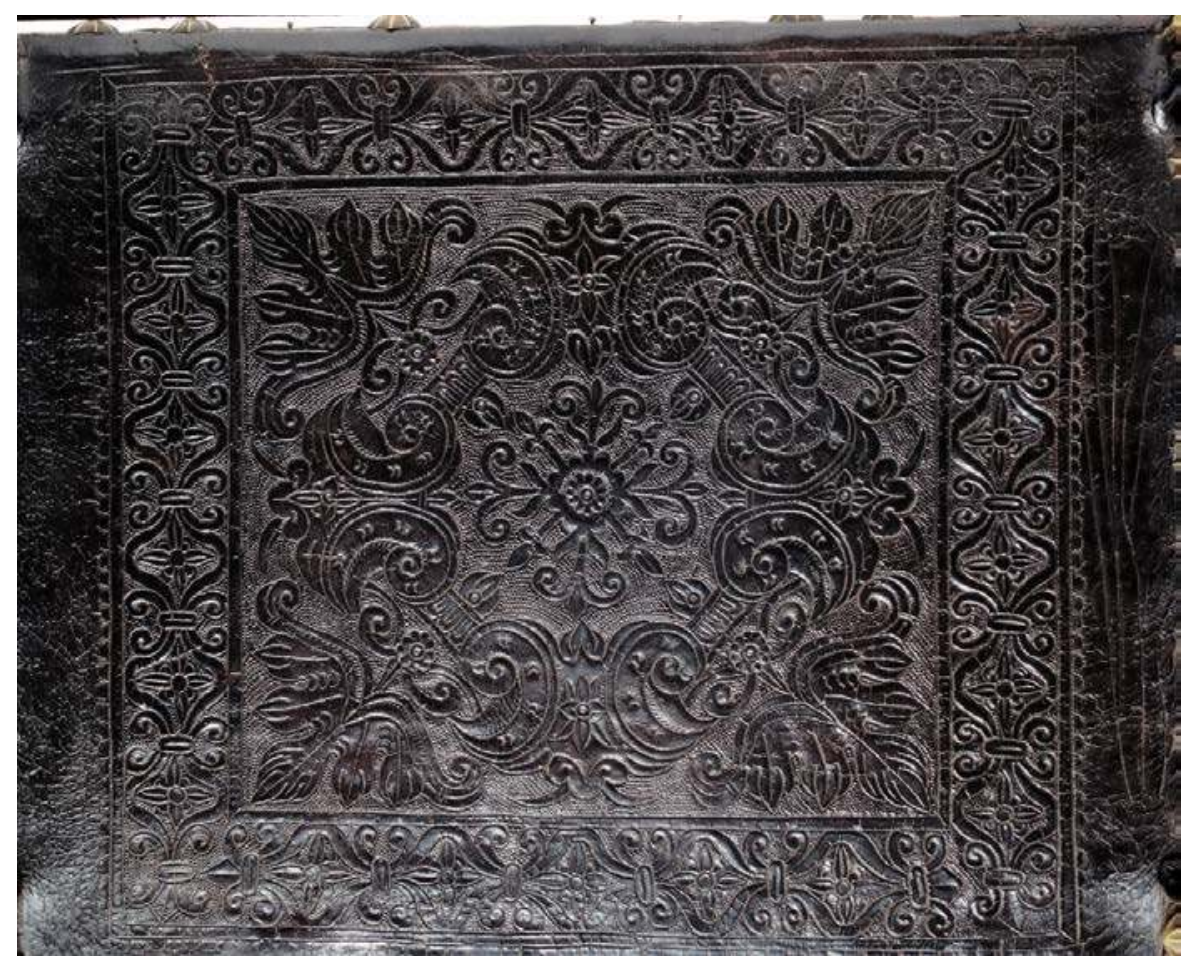

Figura 1B - Assento de cadeira da CMGJ.

Peça $\mathrm{n}^{\circ} 2$ - cadeira da CMGJ

Nos estofos deste exemplar, de estrutura semelhante à cadeira anterior, encontram-se triângulos, obtidos pela justaposição de curvas cinzeladas, e colocados à esquerda e 
direita da larga moldura. O rameado arcaico da moldura, inscrito em amplos SS, tem semelhanças com o seguinte, sendo, todavia, menos requintado. Neste rameado, é de notar pequenos enrolamentos, relembrando medalhões que acompanham alguns "suras", elaborados no al-Andalus nos séculos XI e XII; adiante, na peça n ${ }^{\circ}$ s 3 e 4, veremos de novo este esquema arcaico. Em cada canto encontram-se flores aparentadas à palmeta.

Os motivos centrais do espaldar são, supostamente, armas de aliança, a que não falta a fantasia. Os arcos podem ser lidos como a letra M, encimada por uma coroa de conde, de sete pérolas (o clássico são nove pérolas). No escudo, no peito da ave estão representadas as armas plenas de Coelho (na bordadura estão oito coelhos, quando o clássico são cinco). Como suporte da heráldica está um dragão marinho. Tal como na peça seguinte, o ferramental resume-se a uma goiva em "v", e um cinzel curvo. Os coelhos foram executados um a um, e não por punção única.

O assento (figura 2A) faz par com o espaldar e, como era usual, o motivo é de inspiração vegetalista, dispensando a brasonária. Os rameados simétricos a partir de uma flor central parecem derivar das palmetas califais. A flor central é aparentada ao antiquíssimo motivo da flor quadripétala sobre quadrado, o que acrescenta raridade e importância a esta peça; é outro dos pouquíssimos elementos partilhados com os guadamecis de 1500, portugueses e espanhóis.

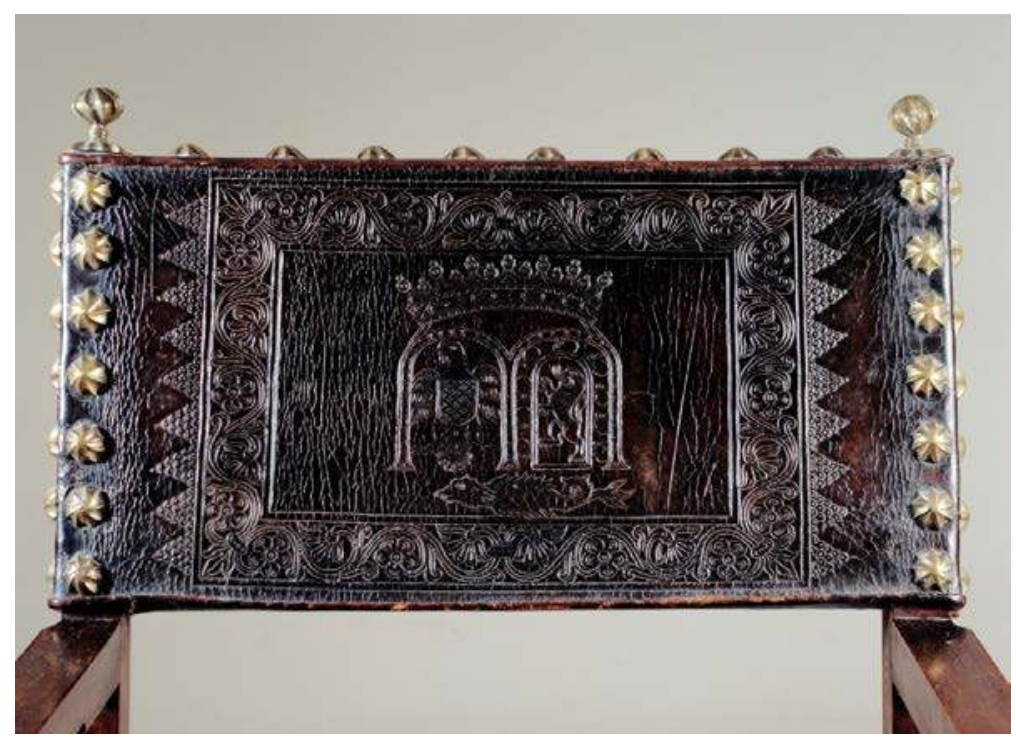

Figura 2 - Espaldar de cadeira da CMGJ. 


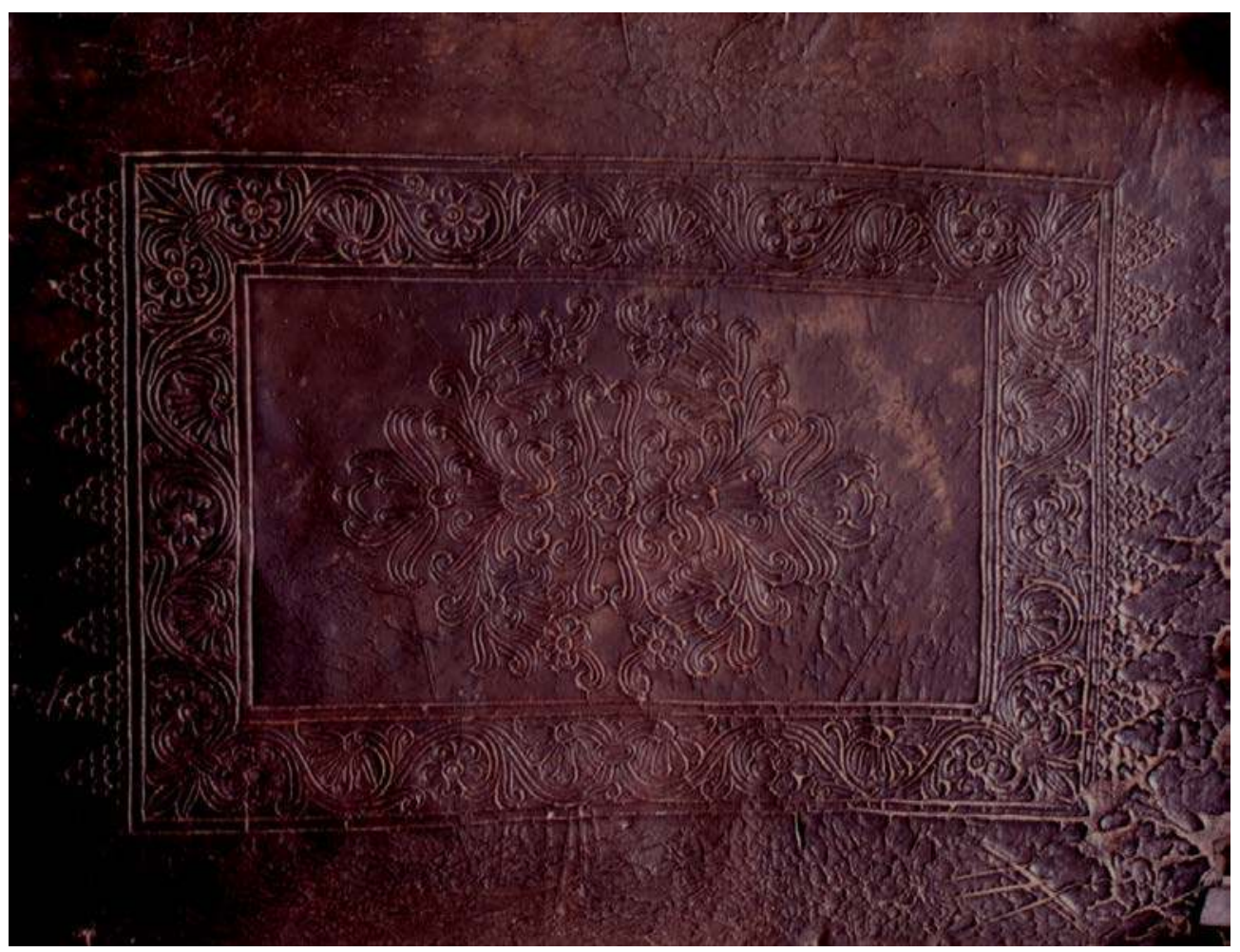

Figura 2A - Assento de cadeira da CMGJ.

Peça $\mathrm{n}^{\circ}$ 3, cadeira da CMGJ

A cadeira é semelhante àquela vista anteriormente, na figura 1. A pregaria que fixa os estofos à madeira também é rara, e deverá ser a original, tal como os dois pináculos cravados no topo do espaldar. Os couros gravados do espaldar (figura 3) mostram um escudo, contendo as armas plenas de Sousa de Arronches sob coroa de duque; o brasão de armas é dos Duques de Lafões (chefes da Casa de Sousa), e que foram os primeiros a utilizar estas armas. Os meios círculos sobre os enrolamentos florais estilizados parecem decorrer do desenvolvimento do acanto califal. Por sua vez, os pequenos enrolamentos nos rameados parecem derivar da estilização vegetalista vista em medalhões florais acompanhando "suras" do Corão (figura 3A), já referidos para a peça anterior. O espaldar tem um rameado arcaico na moldura, em estrutura de grandes SS deitados, limitada, à esquerda e à direita, por triângulos de curvas justapostas, executadas por um cinzel curvo. 
Esta cadeira tem semelhanças, no modelo e na moldura lavrada, com outra, presente no Museu Nacional de Arte Antiga ${ }^{101}$, assim como com a peça anterior deste estudo. Quanto ao assento, o original ter-se-á estragado e foi substituído por um péssimo exemplar, que denota a falta de capacidades do pretenso gravador, de uma época recente onde já não havia exames nem juízes de ofício. Nunca saberemos o grau de distorção que o gravador, talvez na época em que a estrutura foi substituída, imprimiu ao desenho. Parece só ter restado os triângulos, limitando uma moldura devassada pelo simplório e o fácil; as volutas são invenção, mas as cabeças de ave deixam-me na dúvida se existiriam no original, sabendo que, muitas vezes, a gravura partilhava figuras zoomórficas com os têxteis. A própria texturização do assento parece ter sido realizada com um pequeno cinzel curvo, e não com o tradicional "fosco" de grão, usado desde o Gótico até ao Rococó.

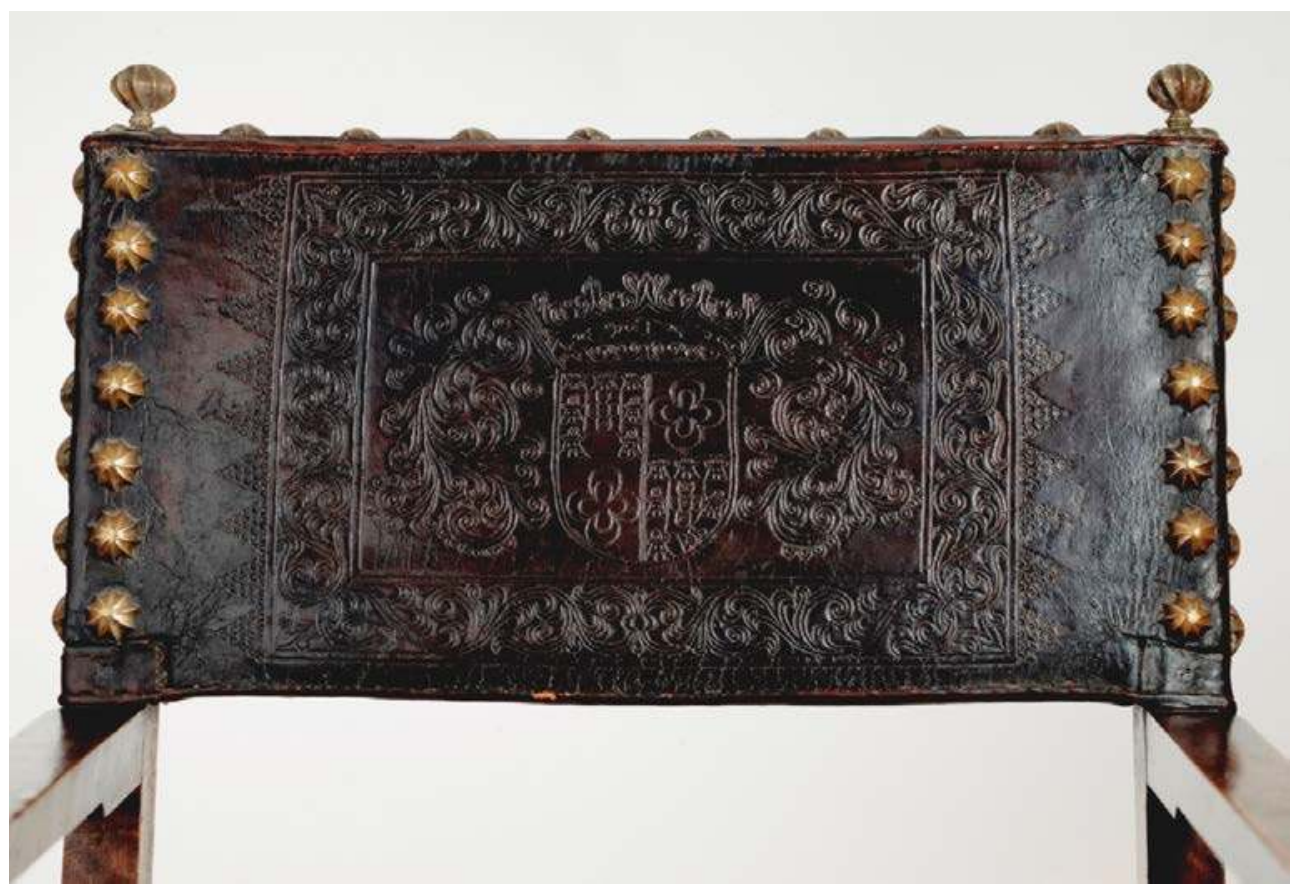

Figura 3 - Espaldar de cadeira da CMGJ.

${ }^{101}$ MOBILIÁRIO Português. Roteiro. Lisboa: Museu Nacional de Arte Antiga / Instituto Português de Museus, 2000, p. 50; PEREIRA, Franklin - "Las influencias del Califato de al-Andalus", p. 513, figura 11.

Medievalista online № 22 | Julho - Dezembro 2017 ( IEM - Instituto de Estudos Medievais 25 www2.fcsh.unl.pt/iem/medievalista 


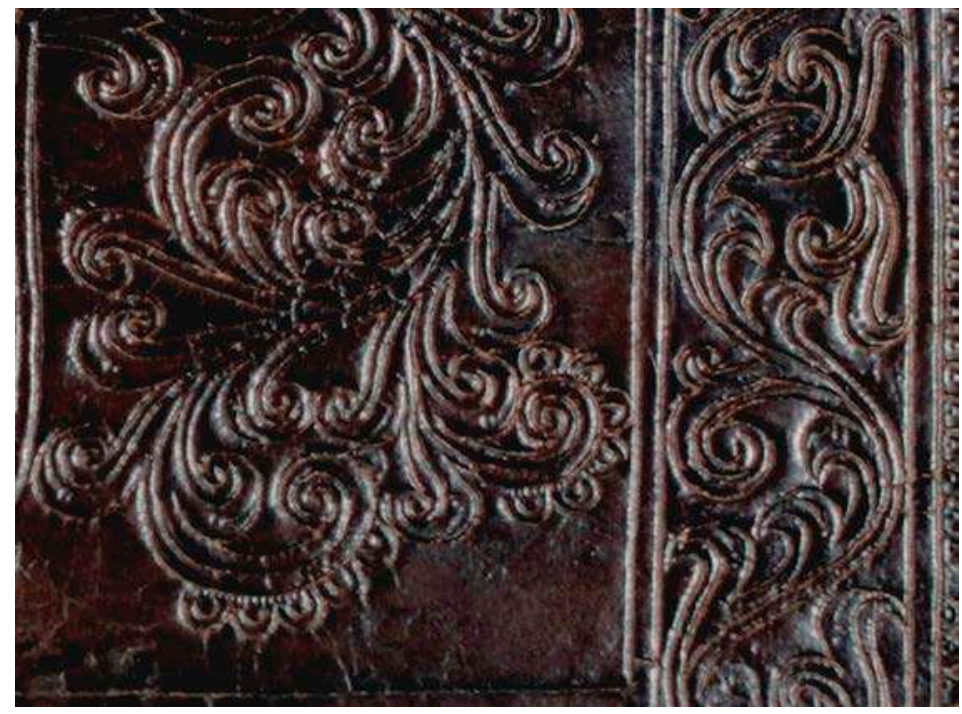

Figura 3A - Detalhe do espaldar de cadeira da CMGJ: moldura e estilização floral em torno do brasão.

Peça $\mathrm{n}^{\circ} 4$ - espaldar da FGJ

$\mathrm{O}$ espaldar apresenta os cânones correntes da época mudéjar do século XVI/inícios do século XVII, já estudados nas obras anteriores (cadeiras n.s 1 a 3): nove triângulos escalonados, à esquerda e direita da moldura, estando esta elaborada por estilização vegetalista assente em SS, produzindo, nos quatro cantos, uma folha com semelhanças com a palmeta (figura 4A). No campo, o brasão central, sob o elmo, está lavrado com as armas de Pereira de Castro. $\mathrm{O}$ aspecto de pequenas folhas enroladas, que se encontra no rameado que rodeia o brasão, é outra recriação mudéjar da estilização vegetalista já vista em ornamentos de "suras" do Corão.

Neste espaldar, além da tradicional goiva em "v" cortante, o artífice gravador usou um cinzel não-cortante em curva (empregue para formar os triângulos laterais), uma punção de bola pequena (apresenta-se entre cada curva dos triângulos), um outro cinzel de curva pequena (encontra-se nos rameados) e uma punção de grande bola (marcada no brasão central). Este espaldar devia estar fixo a uma cadeira semelhante àquela da figura 1. $\mathrm{O}$ espaldar desta última cadeira, ilustrado adiante (figura 5B), distingue-se deste apenas no brasão. É de crer que este espaldar, o seu assento correspondente (figura 5), e aqueles da cadeira "despaldas" lisboeta, ilustrados adiante - figura 5A e figura 5B -, são gravuras da mesma oficina mudéjar portuguesa, sem eliminar a hipótese de várias oficinas partilharem os mesmos motivos requeridos pela elite cristã de então. 


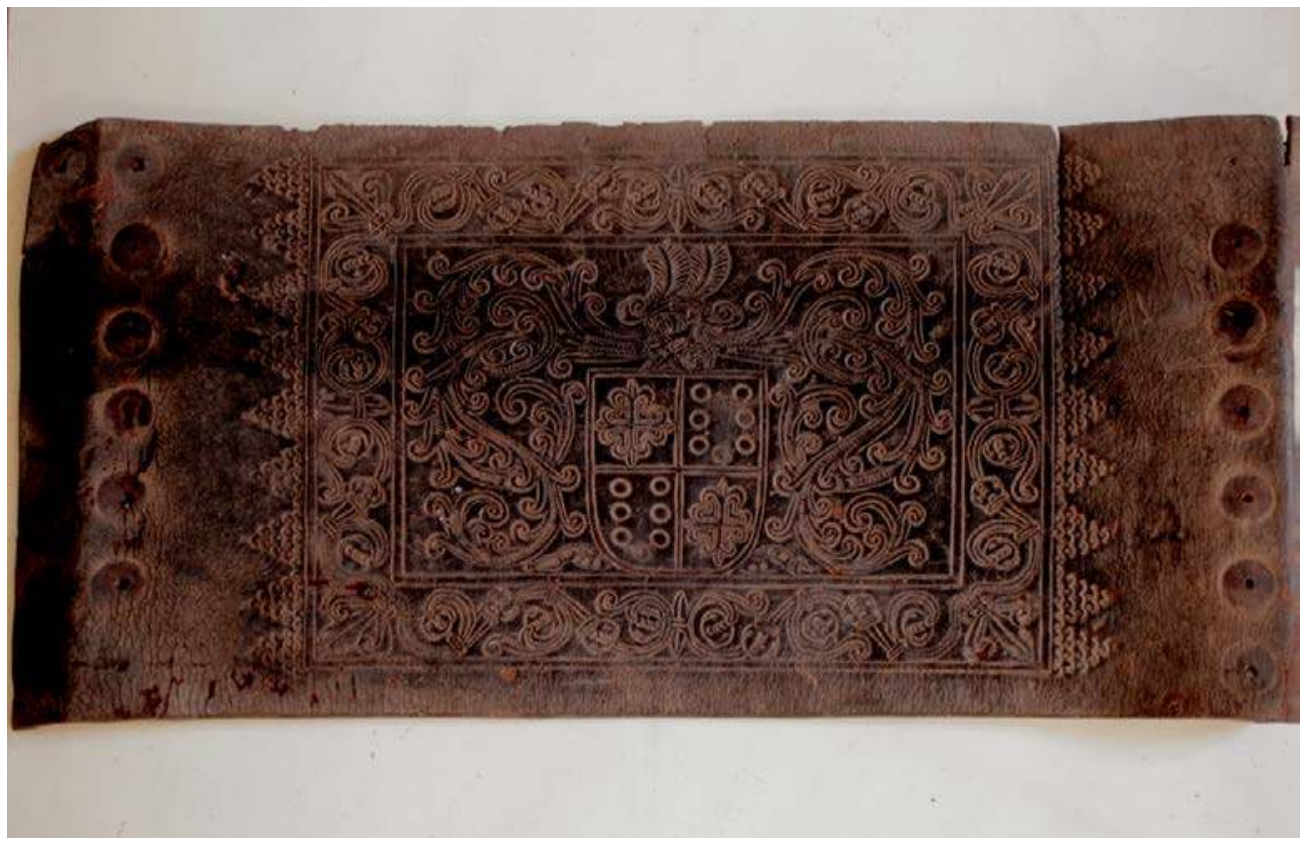

Figura 4 - Espaldar da FGJ.

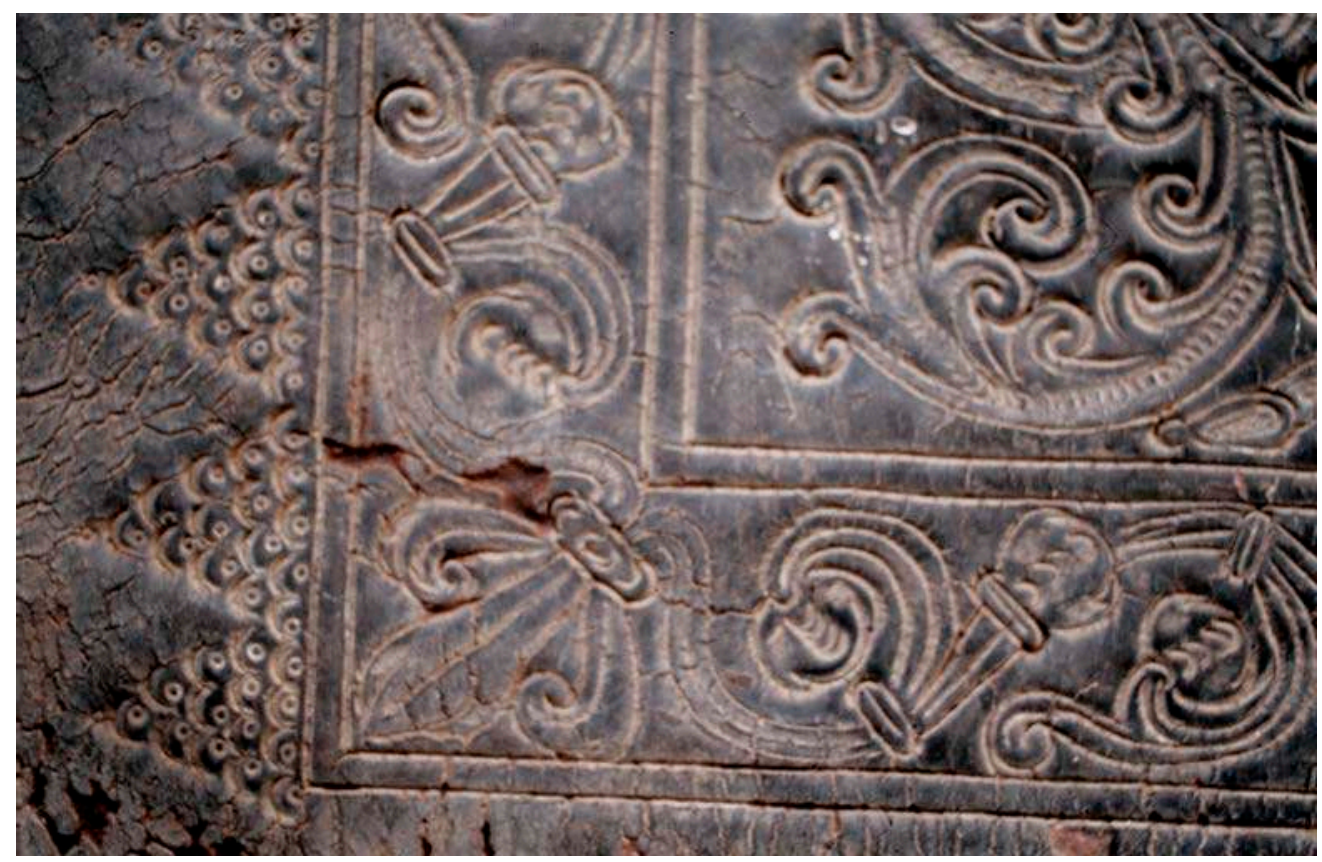

Figura 4A - Detalhe de um canto de espaldar da FGJ.

Peça $\mathrm{n}^{\circ} 5$ - assento da FGJ

Seco e rasgado, retirado da estrutura (que deveria ser como a das peças $n^{\circ} \mathrm{s} 1$ a 3 ), este assento é outra gravura mudéjar, lavrada à goiva; é o par correcto do espaldar atrás referido (figura 4). No medalhão central, ovalado, dispõem-se exteriormente quatro 
grandes palmetas estilizadas. A larga moldura rectangular repete uma estrutura semelhante ao espaldar anterior: estilização vegetalista inscrita em SS, com o que parece ser uma palmeta nos quatro cantos; à esquerda e à direita encontram-se nove triângulos escalonados, obtidos pela justaposição de curvas cinzeladas. Um cinzel curvo foi também usado para gravar o ornamento interno do medalhão, das palmetas e das pequenas flores entre estas; um outro cinzel curvo, pequeno, foi utilizado para decorar interiormente os "anéis" donde brotam as quatro palmetas e o centro de medalhão floral; uma punção de ponto foi aplicada no centro destes "anéis".

No antiquário "Galeria da Arcada", em Lisboa, entre as várias cadeiras expostas, encontrei uma “d'espaldas” bastante intacta, semelhante à figura 1, cujo assento (figura 5A), menos gasto, repete este desenho da FGJ. Existem pequenas diferenças nesta gravura: as pontas das palmetas, à esquerda e direita, tocam na moldura; as flores entre as palmetas não são as mesmas; nas palmetas, a curva cinzelada interna está acompanhada por uma outra curva pequena. É fácil de admitir que ambas são obra de uma mesma oficina, sem colocar de lado a hipótese em serem obra de oficinas diferentes, partilhando o mesmo esquema estético.

A cadeira lisboeta é, tal como as cadeiras "d'espaldas" da CMGJ (nº 1 a 3), uma excelente réplica; os cravos serão, no entanto, os originais, cujo desenho "aos gomos" foi abandonado nos inícios do século XVII, passando a usar-se cravos de cabeça em meia esfera. Note-se, ainda, que o assento lisboeta (figura 5A) foi cosido a um outro couro, salvando-o da eliminação. O espaldar desta cadeira (figura 5B) é o par correcto do assento. A moldura e os triângulos escalonados repetem-se, enquanto o motivo central é um brasão sob elmo, em que aquele encerra um vaso de flores. O rameado que rodeia o brasão é outra versão mudéjar da estilização vegetalista, semelhante a outro, estudado páginas atrás (peça $\mathrm{n}^{\circ} 4$ ). Aliás, a diferença entre o espaldar lisboeta e a peça $n^{\circ} 4$ da FGJ encontra-se apenas no brasão. 


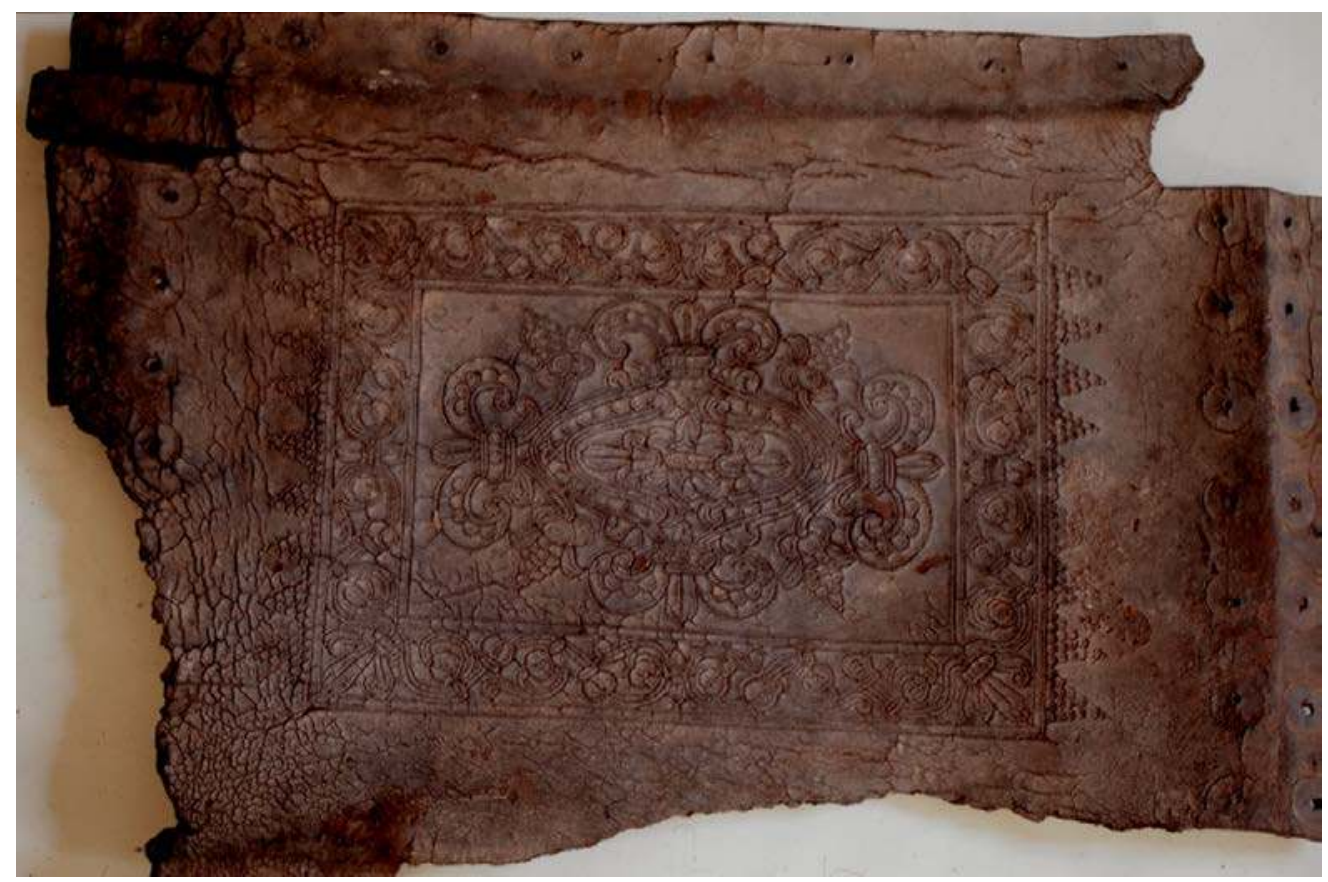

Figura 5 - Assento da FGJ.

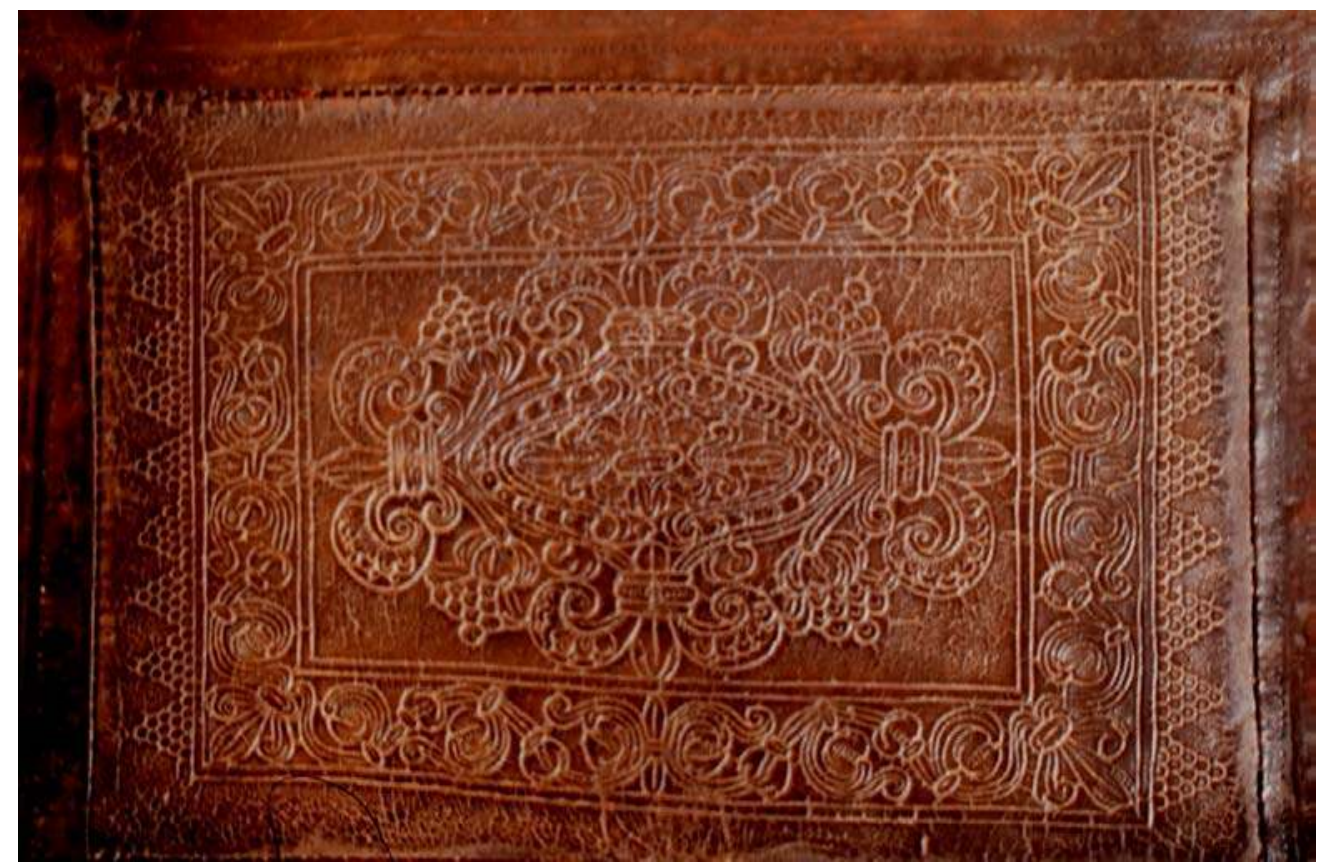

Figura 5A - Assento, ainda em bom estado, em cadeira do antiquário "Galeria da Arcada" (Lisboa). 


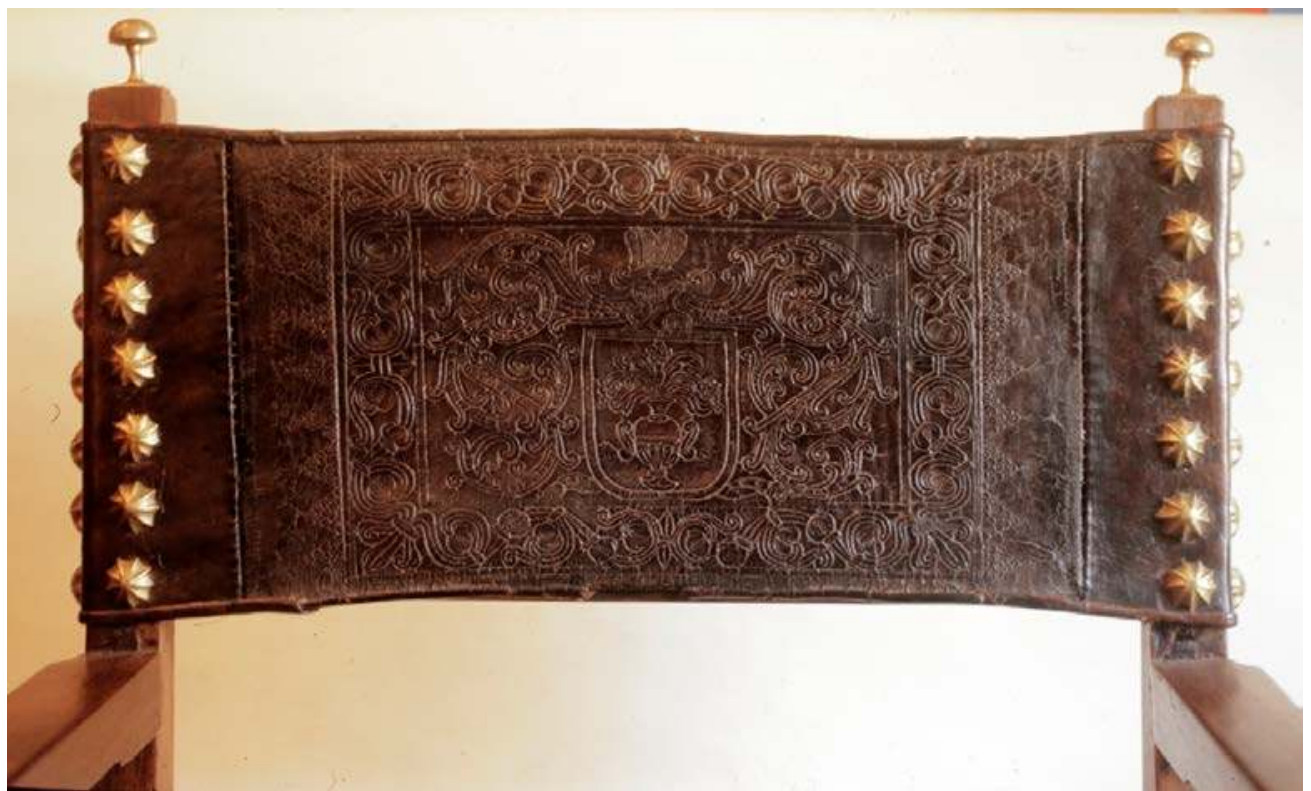

Figura 5B - Espaldar dessa peça. Cadeira do antiquário "Galeria da Arcada” (Lisboa).

Peça $\mathrm{n}^{\circ} 6$ - espaldar da FGJ

Este espaldar é de inícios do século XVII. O brasão central é dos Senhores de Távora; o rameado que o rodeia inscreve-se nos modelos renascentistas, mas parece uma versão menos elaborada, o que faz supor a mão de um artífice ainda não examinado para mestre; outra hipótese é se tratar de um lavrado produzido fora das principais cidades da arte (Porto, Lisboa, Coimbra), e daí a leitura que o gravador fez de estilização vegetalista. A larga moldura às ondas é um prolongamento mudéjar, já estudada nos couros lavrados desta época de transição ${ }^{102}$ e que permaneceu na arte popular do sul ibérico $^{103}$.

O gravador recorreu à goiva em "v" cortante, e a alguns cinzéis não cortantes, para elaborar a flor do elmo, as cunhas do brasão, as linhas rectas e curvas na folhagem e o zig-zag encordoado da fina moldura interna. Uma punção de grão texturou o campo do lavrado, assim como o do brasão. Uma punção de bola foi usada no brasão. Tal como o espaldar e assentos anteriores, este devia estar fixo a uma cadeira semelhante à atrás considerada (figura 1).

\footnotetext{
102 PEREIRA, Franklin - As cadeiras em couro lavrado, p. 227; PEREIRA, Franklin - O couro lavrado no Museu Municipal, pp. 67 a 69.

${ }^{103}$ PEREIRA, Franklin - "Identidade e memória", p. 220.
}

Medievalista online $N^{\circ} 22$ | Julho - Dezembro 2017 @ IEM - Instituto de Estudos Medievais 30 www2.fcsh.unl.pt/iem/medievalista 


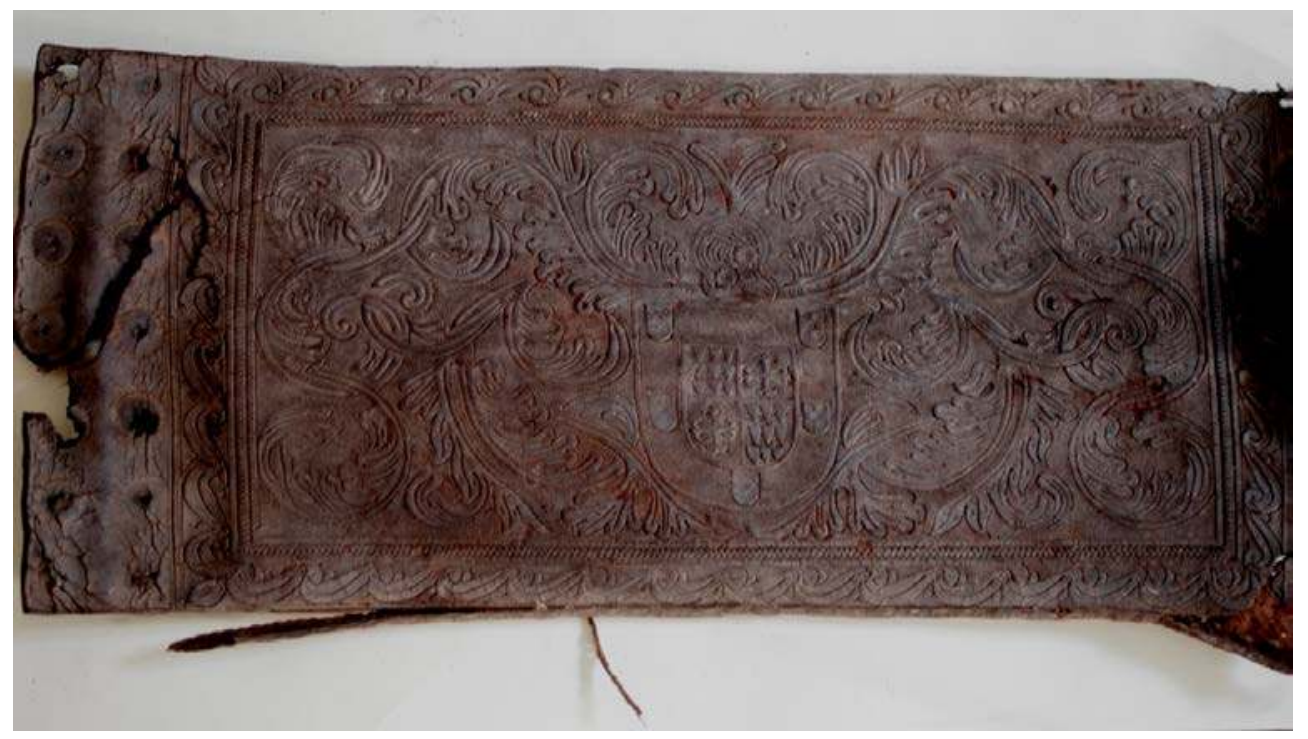

Figura 6 - Espaldar da FGJ.

Peça $\mathrm{n}^{\circ} 7$ - assento da FGJ

Muito estragado e retirado da estrutura - que deveria ser como aquela anteriormente ilustrada (figura 1) -, este assento (não ilustrado) é mais uma versão da arte mudéjar no couro lavrado. Elaborado à goiva, o assento apresenta uma grande flor central de oito pétalas, inscrita num círculo, que relembra a arte popular. Rodeiam-no estilizações e enrolamentos semelhantes às presentes num assento da CMGJ, atrás estudado (figura 1B). A larga moldura assenta no arcaico esquema das ondas ou grandes SS deitados, estando ela própria emoldurada, interna e externamente, por uma fina moldura de ondulados (obtidos pela justaposição de curvas, realizadas por um cinzel não-cortante); finalmente, à esquerda e à direita, estão seis triângulos escalonados, também realizados por um cinzel curvo. Além da goiva em "v" cortante e de três cinzéis em curva (aplicados na moldura ondulada, nas pétalas e nos enrolamentos vegetalistas), o artífice usou um texturador de grão no fundo.

Peça $\mathrm{n}^{\circ} 8$ - assento da FGJ

Este assento (ilustrado apenas com um detalhe), bastante usado, é muito semelhante ao anterior, sugerindo serem ambos obra da mesma oficina, ainda com motivos mudéjares. Mantém a larga moldura às ondas (já referida na peça anterior), e duas outras molduras finas (interna e externamente), aqui elaboradas num simples padrão de curvas seguidas, criando como que escamas em linha; na linha exterior da frente e na de trás, o gravador aplicou também o mesmo cinzel curvo, para criar um padrão contínuo de curvas, como 
mostra o detalhe (figura 7). É de admitir que este acrescento ao comprimento do rectângulo lavrado tenha sido realizado para um enquadramento igualizado no assento; tratar-se-á, assim, de um ajuste, sem que o gravador necessitasse de alterar o desenho central e as medidas das molduras. De novo, exteriormente à moldura, à esquerda e à direita, encontram-se oito triângulos escalonados. Tal como na peça anterior, o gravador usou goiva em "v" cortante, e três cinzéis não-cortantes em curva, e um em linha recta; o fundo foi texturado com a punção de grão.

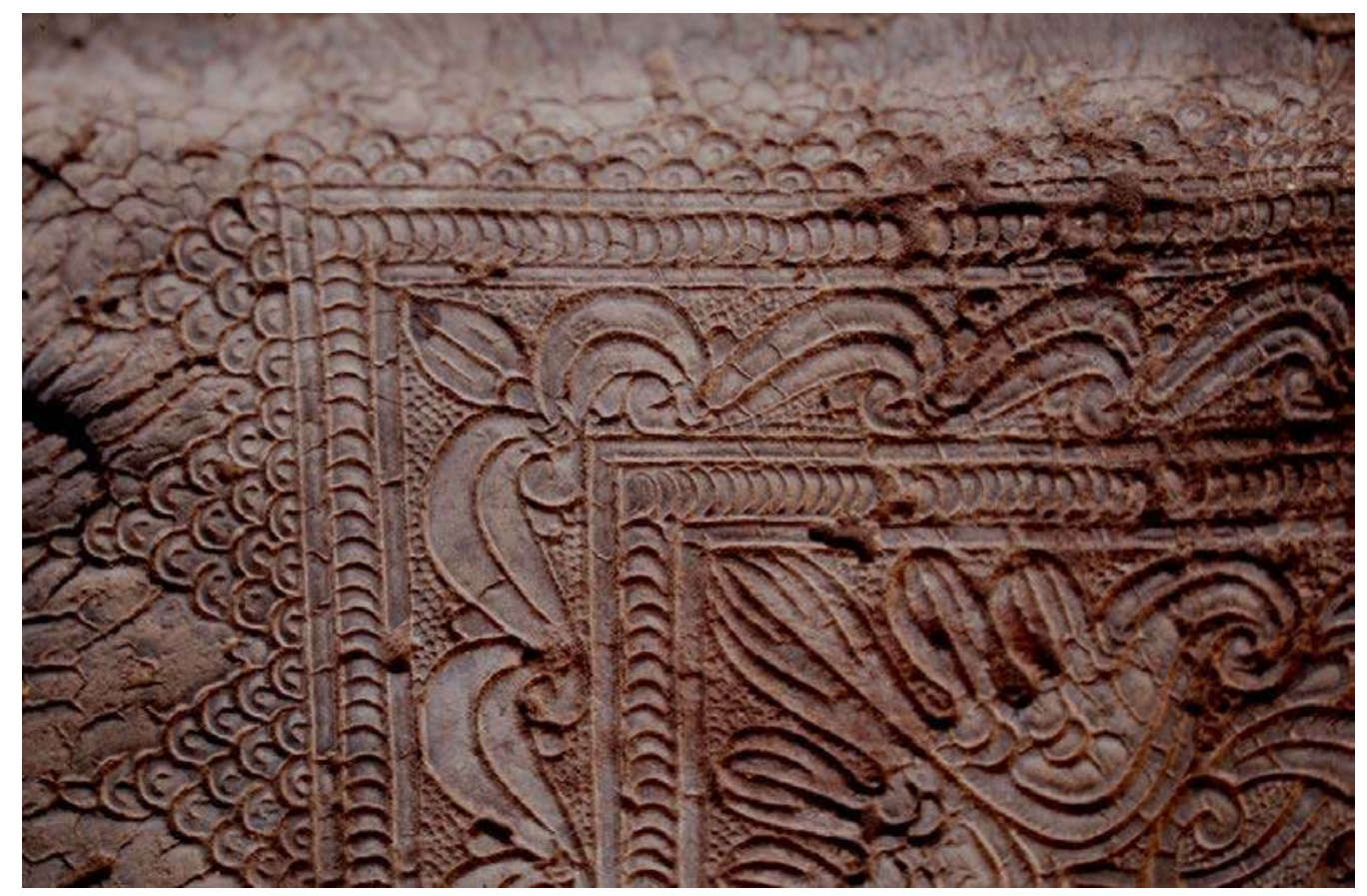

Figura 7 - Detalhe de assento da FGJ. 


\section{Referências bibliográficas:}

\section{Fontes impressas}

LIVRO das Posturas Antigas. Lisboa: Câmara Municipal de Lisboa, 1974.

LIVRO DOS REGIMENTOS dos officiaes mecânicos da mui nobre e sempre leal cidade de Lisboa (1572). Ed. e prefácio por Virgílio CORREIRA. Coimbra: Imprensa da Universidade, 1926.

\section{Estudos}

AGUILÓ ALONZO, Maria Paz - "Cordobanes y guadamecíes”. in BONET CORREA, António - Historia de las artes aplicadas y industriales en España. Madrid: Editorial Cátedra, 1982, pp. 325-335.

- El mueble clásico español. Madrid: Editorial Cátedra, 1987.

- El mueble en España, siglos XVI-XVII. Madrid: Consejo Superior de Investigaciones Cientificas / Ediciones Antiqvaria, 1993.

- "Cordobanes y guadamaciles". in El arte en la piel. Vic: Museu de l'Art de la Pell / Fundación Central Hispano, 1998, pp. 17-31.

- “Cordobanes y guadameciles”. Summa Artis LXV (1999), pp. 259-297.

AL-RASI, Isa Ibn Ahmad - Anales Palatinos del Califa de Córdoba al-Hakam II, 360-

361 H. - 971-975 J. C. Madrid: Sociedad Estudios y Publicaciones, 1967.

ÁLVARO ZAMORA, María Isabel - "Encuadernaciones mudéjares”. Artigrama 23 (2008), pp. 445-481. 
ÁLVARO ZAMORA, María Isabel; MONDINGORRA LLAVATA, María Luz; GIASANTE, Donatella - Els vestits del saber. Enquadernacions mudèjars a la Universitat de València. Valência: Universitat de València, 2003.

ANDALOUSIES. de Damas à Cordoue. Paris: Institut du Monde Arabe / Hazam, 2000.

(AL-)ANDALUS: las artes islámicas en España. Madrid: Ediciones El Viso, 1992.

ARIÉ, Rachel - Miniatures hispano-musulmanes: recherches sur un manuscrit arabe illustré de l'Escurial. Holanda: E. J. Brill, 1969.

ART en la pell: cordovans $i$ guadamassils de la col.lecció Colomer Munmany. Barcelona: Fundació la Caixa / Generalitat de Catalunya, 1992.

(EL) ARTE en la piel - Colección A. Colomer Munmany. Madrid: Fundación Central Hispano / Museu de l'Art de la Pell, 1998.

ASIA, ruta de las estepas: de Alejandro a Gengis Khan. Barcelona: Fundación La Caixa, 2001.

BARROS, Maria Filomena Lopes de - A comuna muçulmana de Lisboa: sécs. XIV e $X V$. Lisboa: Hugin, 1998.

- Tempos e espaços de mouros: a minoria muçulmana no reino português (séculos XII $a X V)$. Lisboa: Fundação Calouste Gulbenkian, 2007.

BARRUCAND, Marianne; BEDNORZ, Achim - Arquitetura islámica en Andalucía. Colónia: Taschen, 1992.

CARPALLO-BAUTISTA, Antonio - "Las encuadernaciones mudéjares de lacerías, tipo «toledano»y «salmantino», en la Catedral de Toledo". Al-Qantara XXXIII/2 (julio-septiembre 2012), pp. 375-404. 
CRESWELL, K. A. C. - Early Muslim Architecture. Umayyads. A. D. 622-750. Oxford: Claredom Press, II, 1969.

CRUZ, António - Os mesteres do Porto. Porto: Imprensa Industrial Gráfica, 1943.

EGRY, Anne de - Um estudo de "O Apocalipse do Lorvão" e a sua relação com as ilustrações medievais do apocalipse. Lisboa: Fundação Gulbenkian, 1972.

(EL) ESPLENDOR de los omeyas cordobeses. La civilización musulmana de Europa Occidental. Madinat al-Zahra: Fundación El Legado Andalusí / Junta de Andalucia, 2001.

ETTINGHAUSEN, Richard - "Notes on the lusterware of Spain". Ars Orientalis I (1954), pp. 133-156.

EXPOSICIÓN de encuadernaciones españolas, siglos XII al XIX. Madrid: Sociedad Española de Amigos del Arte, 1934.

FEDUCHI, Luís - Historia del Mueble. Madrid: Afrodisio Aguado, 1946.

- Antologia de la Silla Española. Madrid: Afrodisio Aguado, 1957.

FERRANDIS TORRES, José - Marfiles árabes de Occidente, siglos X y XI. Vol. I e II. Madrid: Estanislao Mestre, 1935-1940.

- Cordobanes y guadamecíes: catálogo ilustrado de la exposición. Palácio de la Biblioteca y museos nacionales. Madrid: Sociedad Española de Amigos del Arte, 1955.

GUADAMASSILS antics a Catalunya / Guadamecíes antiguos en Cataluña / Ancient Gilt Leather in Catalonia. Vic: Museu de l'Art de la Pell / Ayuntament de Vic, 2001.

HAMILTON, R. W. - Khirbat al-Mafjar: an Arabian mansion in the Jordan valley. Oxford: Claredom Press, 1959. 
KYBALOVÁ, Ludmila - Les tissus coptes. Paris: Cercle d'Art, 1967.

MATILDA ANDERSON, Ruth - "El chapin y otros zapatos de la Alhambra". Cuadernos de la Alhambra 5 (1969), pp. 17-41.

MOBILIÁRIO Português. Roteiro. Lisboa: Museu Nacional de Arte Antiga / Instituto Português de Museus, 2000.

PASSOLA, José M. - Artesania de la piel. Encuadernaciones en Vich, siglos XII-XV. Vic: Colomer Munmany, 1968.

PAVÓN MALDONADO, Basílio - "La formación del arte hispanomusulmán: hacia un corpus de la ornamentación geométrica rectilínea”. Al-Andalus XXXVIII-1 (1973), pp. 195-242.

- Arte toledano: islámico y mudéjar. Madrid: Instituto Hispano-árabe de Cultura, 1988.

- El arte hispano-musulmán en su decoración floral. Madrid: Agencia Española de Cooperación Internacional, 1990.

PEREIRA, Franklin - As cadeiras em couro lavrado e os guadamecis do Museu de Pontevedra. Pontevedra: Museu de Pontevedra, 2000.

- O couro lavrado no mobiliário artístico de Portugal. Porto: Lello e Irmão, 2000.

- O couro lavrado no Museu Municipal de Viana do Castelo: da arte "mourisca" à época barroca. Viana do Castelo: Museu Municipal, 2000.

- "Leather decoration tools of the Iberian tradition, since the 13th century". Tools and Trades 12 (2000), pp. 1-25.

- "Couros artísticos nos interiores abastados de Arraiolos e Montemor-o-Novo, no século XVII". Almansor 1-2 ${ }^{\mathrm{a}}$ série (2002), pp. 145-168. 
- "Cueros artísticos en el Museo Arqueológico Nacional". Boletín del Museo Arqueológico Nacional 20 (2002), pp. 215-241.

- "Las influencias del Califato de al-Andalus en los cueros labrados de Portugal del siglo XVI". in Mil años de trabajo del cuero. Actas del II Simposium de Historia de las Técnicas. Córdova: Sociedad Española de Historia de las Ciências y de las Técnicas / Universidad de Córdoba, 2003, pp. 501-518.

- "A arte dos pastores do sul peninsular: arquétipos em final de estrada". in Actas das III Jornadas Internacionais de Vestígios do Passado / Almeida, 2007. Póvoa do Varzim: AGIR / Associação para o Desenvolvimento Sócio-cultural, 2007, pp. 218-223.

- "O couro e o Islão na Península Ibérica: identidade cultural, pedagogia e património. Reflexões em torno de uma tese de mestrado". Ensinarte / Revista das artes em contexto educativo 10 (2007), pp. 22-33.

- "Identidade e memória nas artes do couro de linhagem ibero-muçulmana". in Actas do I Seminário Internacional de Memória e Cultura Visual/ Póvoa do Varzim, 2007. Póvoa do Varzim: AGIR/Associação para o Desenvolvimento Sócio-cultural, 2008, pp. 195220.

- "A sul do rio Mondego. Arcaísmo, simbologia e transmigração de ornamentos nas artes populares do sul ibérico". A Cidade de Évora $2^{\mathrm{a}}$ série, 7 (2009), pp. 525-543.

- "Identidade e marcas de cultura - a propósito de uma cadeira em couro lavrado na igreja de Santa Eufémia da Chancelaria (Torres Novas)". Nova Augusta 21 (2009), pp. 143-153.

- Ofícios do couro na Lisboa medieval. Lisboa: Editora Prefácio, 2009.

- "Eqqus cursare - uma viagem a partir do Festival Anual do Cavalo na Golegã". Nova Augusta 22, (2010), pp.157-182. 
- "Estéticas em trânsito: a partilha do ornamento da cerâmica do Gharb al-Andalus com outros artefactos”. Arqueologia Medieval 12 (Outubro 2012), pp. 193-200.

- "A grande viagem da flor quadripétala: um estudo a partir da fíbula da escultura “Nossa Senhora do Ó” do Museu Municipal Carlos Reis/Torres Novas". Nova Augusta 24 (2012), pp. 183-196.

- "Uma leitura do painel "Santiago aos Mouros" do Museu de Arte Sacra de Mértola - a equitação medieval e os artefactos da guerra a cavalo". Arqueologia Medieval 12 (Outubro 2012), pp. 279-292.

- "Os couros artísticos: modas e estéticas em trânsito". in Sphera Mundi - Arte e cultura no tempo dos Descobrimentos / Congresso Internacional. Lisboa, 13-15 Outubro 2015. Vale de Cambra: Caleidoscópio, 2015, pp. 297-312.

- "Couros dourados" / guadamecis dos Países Baixos em Portugal (séculos XVIIXVIII)”. Al-Madan, $2^{\mathrm{a}}$ série, 19/II (Janeiro 2015), pp. 117-132.

- "The Charola de Tomar: early 16th century mould-embossed gilt leather, glued to stone walls". Newsletter. Stroke-up-Trent: Archeological Leather Group 43 (Março 2016), pp. 14-16.

PEREIRA, Paulo - História da arte em Portugal. Lisboa: Círculo de Leitores, I, 1995. PÉREZ HIGUERA, Teresa - Objetos y imagenes de al-Andalus. Madrid: Editorial Lundwerg, 1994.

PEREZ, Rosa Maria (org.) - Memórias árabo-islâmicas em Portugal. Lisboa: Comissão Nacional para a Comemoração dos Descobrimentos Portugueses, 1997.

PINTO, Augusto Cardoso - Cadeiras portuguesas. Lisboa: A. C. Pinto, 1952.

PORTUGAL ISLÂMICO: os últimos sinais do Mediterrâneo. Lisboa: Museu Nacional de Arqueologia / Instituto Português de Museus, 1998. 
REAL, Manuel Luís - "Os Moçárabes do Gharb português”. in Portugal Islâmico: os últimos sinais do Mediterrâneo. Lisboa: Museu Nacional de Arqueologia / Instituto Português de Museus, 1998, pp. 35-56.

RICARD, Prosper - Pour comprendre l'art musulman dans l'Afrique du Nord et d'Espagne. Paris: Hachette, 1924.

- "Sur un type de reliure des temps almohades". Ars Islamica I (1934), pp. 74-79.

RICE, David Talbot - "The pottery of Bizantium and the Islamic world". in Studies in Islamic Art and Architecture in Honour of Professor K. A. C. Creswell. Cairo: The American University in Cairo Press, 1965, pp. 194-236.

STIERLIN, Henri - Islão. De Bagdade a Córdova: a arquitectura primitiva do século VII ao século XIII. Colónia: Tachen, 2002.

TORRES BALBÁS, Leopoldo - "De cerámica hispano-musulmana". Al-Andalus IV (1939), pp. 412-432.

- "Las yeserías descubiertas recientemente en las Huelgas de Burgos". Al-Andalus VIII (1943), pp. 209-254.

TORRES, Cláudio (org.) - Cerâmica islâmica portuguesa. Mértola: Câmara Municipal de Mértola / Fundação Gulbenkian / Campo Arqueológico de Mértola, 1987.

YON, Jean-Baptiste - "La época grecoromana - fusión de culturas bajo la impronta helenística”. in Oriente Próximo - Historia y Arqueología. Colónia: Konemann, 2000. 


\section{COMO CITAR ESTE ARTIGO}

\section{Referência electrónica:}

PEREIRA, Franklin - “O couro lavrado de estética mudéjar na Casa-Museu e Fundação

Guerra Junqueiro - memórias do al-Andalus em terras portuguesas”. Medievalista 22 (Julho-Dezembro 2017). [Em linha] [Consultado dd.mm.aaaa]. Disponível em http://www2.fcsh.unl.pt/iem/medievalista/MEDIEVALISTA22/pereira2205.html ISSN 1646-740X.

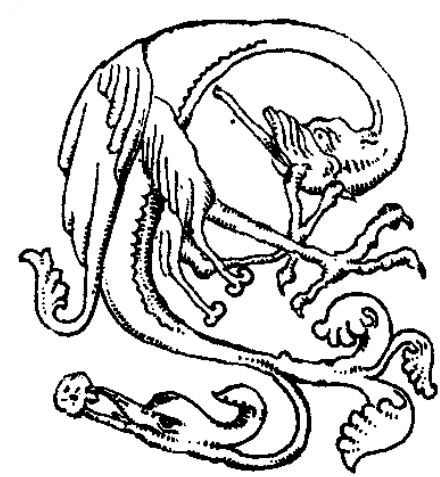

